University of Zurich

Department of Economics

Working Paper Series

ISSN 1664-7041 (print)

ISSN 1664-705X (online)

Working Paper No. 213

\title{
The Effect of All-Day Primary School Programs on Maternal Labor Supply
}

Janina Nemitz

December 2015 


\title{
The Effect of All-Day Primary School Programs on Maternal Labor Supply
}

\author{
Janina Nemitz \\ University of Zurich
}

\begin{abstract}
This study analyzes the effect of all-day (AD) primary school programs on maternal labor supply. To account for AD school selectivity and selection into AD primary school programs I estimate bivariate probit models. To identify these models I exploit variation in the allocation of investments to AD primary schools across time and counties. This variation results from the public investment program "Future Education and Care" (IZBB) which was introduced by the German federal government in 2003. My results indicate for mothers with primary school-aged children in Germany (excluding Bavaria) a significantly positive effect of AD primary school programs on labor supply at the extensive margin. On average, mothers who make use of AD primary school programs are 26 ppts more likely to be employed than mothers who do not make use of these programs. This large effect is robust to alternative specifications and estimation methods and mainly concentrated in states with AD primary school student shares of up to $20 \%$. On the contrary, there is no evidence for an impact of these programs on maternal labor supply at the intensive margin (full-time vs. part-time).
\end{abstract}

Keywords: All-day school programs, after-school care, maternal labor supply

JEL Codes: J13, J21, J22

\footnotetext{
${ }^{\text {* }}$ I am deeply indebted to Johannes Kunz, Harald Mayr, and Rainer Winkelmann for invaluable advice and guidance. Moreover, I wish to thank Uschi Backes-Gellner, Pietro Biroli, Richard Blundell, Stefan Boes, Kristina Hess, Christian Kascha, Edward Lazear, Florian Schaffner, and seminar participants at Lech am Arlberg, Lucerne, Zurich, the "Zurich Workshop in Economics", and the Workshop on "Empirical Analysis of Consumption and Labour Supply Behaviour" at the Study Center Gerzensee for extremely helpful comments and suggestions, and Luca Tonizzo for excellent research assistance. I gratefully acknowledge support and data provided by the Social Pedagogical Institute of the Technical University of Applied Science in Cologne (SPI NRW), the Conference of Ministers of Education and Cultural Affairs of the Länder (KMK), and the German Institute for Economic Research (DIW Berlin).

Address for correspondence: Janina Nemitz, Department of Economics, University of Zurich, Zürichbergstrasse 14, CH-8032 Zurich, Switzerland. Phone: +41 4463422 95; e-mail: janina.nemitz@econ.uzh.ch.
} 


\section{Introduction}

In the last decades many countries have introduced childcare programs to enable mothers to better reconcile work and family life. These programs have reduced the costs associated with childcare by either expanding overall childcare supply or subsidizing the utilization of childcare. As the reduction of childcare costs decreases the opportunity costs of employment, it becomes more valuable for mothers to work (Becker 1991, Ribar 1992). Hence, childcare programs are often associated with positive maternal labor supply responses and an increased demand for childcare. Poor childcare quality or high social costs of using childcare (e.g. loss in social esteem, "Rabenmutter") may, however, suppress maternal use of childcare (Blau \& Robins 1988, Ribar 1992). Moreover, a high initial level of childcare supply and/or maternal employment can limit the scope of such programs (Cascio et al. 2015). A priori, it is thus unclear whether or not maternal labor supply indeed increases in response to childcare programs.

For this reason, many studies have analyzed the impact of childcare programs on maternal labor supply. Most of these studies have focused on the effects of childcare provision for preschool-aged children. Exploiting temporal and regional variation in childcare supply and estimating difference-in-differences models or relying on eligibility cut-offs in an instrumental variable or regression discontinuity setting, these studies provide mixed evidence (Gelbach 2002, Berlinski \& Galiani 2007, Baker et al. 2008, Cascio 2009, Fitzpatrick 2010, Havnes \& Mogstad 2011, and Bauernschuster \& Schlotter 2015). Childcare provision for school-aged children has attracted little attention, although primary school-aged children also require a significant amount of maternal care. In particular, in many European countries the time spent in primary schools is relatively short and after-school care programs are rare, which may result in a large unused maternal labor force potential.

Figure 1 illustrates this problem for Germany. According to the German time use survey 1991/92, mothers whose youngest child is aged 6 to 11 spend, on average, 5.3 hours per day with their children. This is less time than for mothers with preschool-aged children; yet, it is 2 hours more than for mothers whose youngest child is aged 12 to 15 . Taking into consideration that mothers are time-constraint and can invest their time either into childcare or market labor, this negative gradient for the maternal time spent with children implies a positive gradient for maternal employment, i.e. I would expect the adverse effects of children on maternal employment to decline by the age of the youngest child. Data from the German microcensus 2002 show that these expectations are correct. Both the share of employed mothers and the share of full-time employed mothers increase by the age of the youngest child. Thus, Figure 1 suggests that childcare programs for young school-aged children are also likely to increase maternal labor supply at both margins. The mobilization 


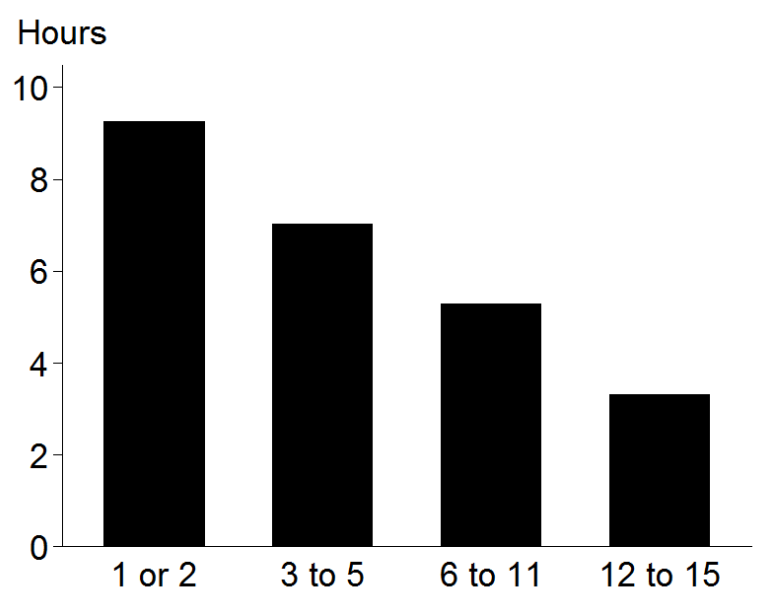

A. Daily time spent with children

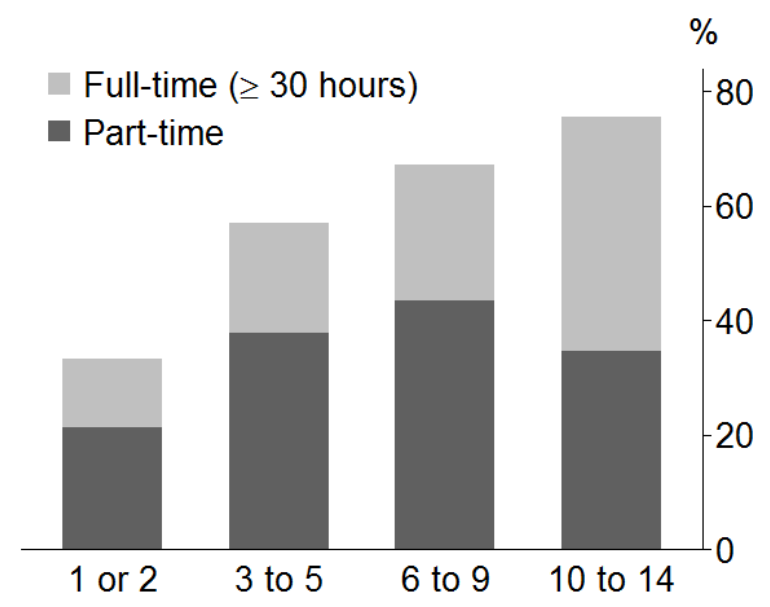

B. Employment shares

Figure 1. Maternal Care and Employment by Age of the Youngest Child

Sources: a) BMFSFJ (1996) = based on data from the German time-use survey 1991/92. b) Kreyenfeld \& Geisler $(2006)=$ based on data from the Microcensus 2002. Own representations.

of the unused maternal labor force potential is one important approach to overcome the skill shortage, problems of pay-as-you go financed social security systems, and old-age poverty of women with children.

Studies which evaluate the impact of childcare provision for (young) school-aged children on maternal labor supply are relatively rare. To the best of my knowledge, there exist only two studies which investigate the impact of after-school care provision on maternal labor supply. Lundin et al. (2008) evaluate the introduction of price caps for childcare in Sweden. Using Swedish register data and focusing on two-parent households with at least one child aged 1 to 9, they estimate matching difference-in-differences models and show that reduced childcare prices have no impact on maternal employment, in general. Splitting the sample by the age of the youngest child, they find small negative effects of prices on full-time employment shares of mothers with school-aged children. For mothers with preschool-aged children no effects on employment were uncovered. Felfe et al. (2015) exploit cantonal variation in the regulations of after-school care provision in Switzerland to analyze the effect of after-school care on parental labor market outcomes. Restricting their analysis to narrow regions along cantonal borders, their reduced form and IV estimates reveal that mothers with 4- to 12-year-old children positively respond to an increased after-school care coverage. More specifically, they find that almost every newly available after-school care slot resulted in one additional full-time employed mother. Likewise, in Lundin et al. (2008) the authors do not find effects of childcare provision on maternal labor supply at the extensive margin.

In addition to these findings, there exists some evidence from Chile which is based on 
the extension of school schedules from half to full day rather than the provision of afterschool center-based care. In 1996, the Chilean government approved a law which increased the time of students spent in school by $35 \%$. Due to financial constraints this reform was gradually implemented leading to substantial variation across municipalities and over time. Contreras et al. (2010) and Berthelon et al. (2015) exploit this quasi-experimental setting and investigate the effects of this reform on different measures of maternal labor market attachment. Both studies provide evidence for a substantial increase in maternal labor force participation. Moreover, Berthelon et al. (2015) show that access to all-day (AD) schools also positively affects permanent maternal labor market attachment. Both the likelihood of mothers to participate for at least six out of twelve months and the fraction of the year that mothers worked or searched for employment increase by 19 ppts in response to a 45 ppts increase of full-day coverage, which is the change required to establish full coverage. Significantly negative effects were uncovered for the number of hours worked (Contreras et al. 2010), which contrasts with the findings for Sweden and Switzerland.

I aim to contribute to this literature by providing further evidence on the effects of childcare provision for school-aged children on maternal labor supply. More specifically, I investigate whether AD primary school programs increase maternal labor supply at both the extensive (employment vs. non-employment) and the intensive margin (full-time vs. parttime employment). My setting is similar to the one in Chile, as I also rely on an expansion of AD schools in a country which was characterized by its half-day school system and a low supply of center-based care for school-aged children pre-investment. Unlike in Chile, the labor force participation of mothers with school-aged children was already at a comparatively high level when the expansion of AD schools was initiated (74\%). Yet, the full-time employment rate was at a relatively low level (35\%). Thus, a priori, the effects of an expansion of AD schools on maternal labor supply are indeterminate.

Furthermore, also in contrast to Chile, in Germany AD school programs were provided on a voluntary basis, i.e. parents were able to decide upon participation or non-participation in $\mathrm{AD}$ schooling of their child according to their preferences. As a consequence, selection into $\mathrm{AD}$ schools and $\mathrm{AD}$ school programs, respectively, needs to be taken into account. Therefore, I estimate bivariate probit models for maternal labor supply at the extensive and the intensive margin conditional on maternal employment. To identify my models I exploit exogenous variation in the investments allocated to AD primary schools across counties and over time. This variation results from the public investment program "Future Education and Care" (in German: Investitionsprogramm "Zukunft Bildung und Betreuung" = IZBB), which was launched by the German federal government in 2003 and has led to a sharp increase of AD primary schools in Germany (by more than 30 ppts until 2009, KMK 2014). 
Thus, this expansion of AD primary schools renders Germany a particularly suitable country for causal analysis. ${ }^{1}$

Using data from the German Socio-Economic Panel (SOEP) and administrative data on AD schools, my results indicate that AD primary school programs substantially increase maternal labor supply at the extensive margin. When compared to mothers with primary school-aged children who do not make use of AD primary school programs, mothers who make use of these programs have a 26 ppts higher probability of being employed. This finding is robust to alternative estimation strategies and specifications. In particular, Two-Stage LeastSquares (2SLS) estimates are of similar magnitude as my bivariate probit estimates. Being less precisely estimated, however, they do not reach statistical significance. This highlights the potential benefit of correctly imposing stronger assumptions - due to the seemingly unrelated structure of the errors bivariate probit coefficients can be more precisely estimated in the presence of selection on unobservables.

Moreover, my findings for the extensive margin reveal two additional important results. First, the large effect on the extensive margin is mainly concentrated in states with AD primary school student shares of up to $20 \%$. Second, contrary to my initial expectations, selection into AD primary school programs based on unobservable maternal characteristics is negative, i.e. mothers with more favorable unobservable labor market characteristics and stronger work preferences are less likely to make use of AD primary school programs. This implies for my estimation that, if I were to ignore selection based on unobservable characteristics, I would actually understate rather than overstate the effect of AD primary school programs on maternal employment.

While this finding of a negative correlation is somewhat counterintuitive at first sight, it is yet compatible with some descriptive evidence on the acceptance of AD schools in Germany. For example, Börner et al. (2010) find that better educated parents and parents with a high socio-economic status often critically oppose AD schools. Presumably, having more resources (financial, social and cultural) they are better able to promote their child's interest. Parents with low socio-economic status and/or migration background, however, often believe that their child benefits from the attendance of AD school programs, as their child gets access to a broad variety of social and cultural activities and can socially interact with peers.

For the intensive margin, there is no evidence for an effect of AD primary school programs

\footnotetext{
${ }^{1}$ Note that this policy can be interpreted as an implicit childcare subsidy for primary school-aged children (cf. Gelbach 2002), as primary schools in Germany provided AD school programs at virtually zero costs. Beblo et al. (2005) evaluate the impact of this expansion of AD primary schools on maternal labor supply in an ex-ante simulation study. The same quasi-experimental setting is used by an independent study (Dehos \& Paul 2015), although the sample, the instrument, and the estimation method differ from those used in this paper.
} 
on maternal labor supply. Due to the smaller sample size, however, coefficients are less precisely estimated. Moreover, sensitivity tests reveal that the results for the intensive margin are not as robust as the results for the extensive margin.

The remainder of this paper is structured as follows: The next section provides some information on the institutional framework in Germany and the IZBB program. Section 3 describes the data and sample selection. Section 4 presents my empirical strategy and discusses the underlying identifying assumptions. Section 5 presents the results and a battery of robustness checks. Section 6 concludes.

\section{Institutional Background}

This section provides some general information on the institutional background in Germany. In particular, I give some details on the primary education system, care for primary schoolaged children, and maternal employment prior to the expansion of AD schools in Germany. I proceed by presenting the IZBB program which has led to this expansion of AD schools. Finally, I briefly discuss AD schools in Germany, as they differ in many respects from AD schools in other countries.

\subsection{Education and Care for Primary School-Aged Children in Germany}

In Germany education policy is regulated by the federal states. As a consequence, the primary education system tends to vary across states. The main differences pertain to the content of teaching curricula, but also other relevant aspects such as the school enrollment age or the duration of primary schooling can be state-specific. Nevertheless, the main characteristics of the German primary education system can be summarized as follows:

- In Germany compulsory primary education starts when children turn six years old. There are, however, some under- and over-aged students because of early and late school enrollment. Between 2003 and 2009 less than 15\% of all school enrollments were early or late school enrollments (Autorengruppe Bildungsberichterstattung 2012, p. 63).

- In Germany primary education lasts four years. Consequently, the majority of children has completed primary school by the age of ten. In Berlin and Brandenburg, however, primary education lasts six years. For the sake of comparison across states, I thus focus on mothers whose children are aged 5 to 10 when attending primary school.

- Pre-investment, primary schools in Germany were mainly organized as half-day schools, i.e. they started at 8 o'clock in the morning and finished between 12 or 1 o'clock. This 
short time spent in school complicated the combination of work and family life for mothers, unless their child was cared for by others.

After-school center-based care was at a relatively low level in 2002. In West Germany (excluding the city states), only $6 \%$ of 6 - to 9-year-old children were offered after-school care. In East Germany, the corresponding share was more than ten times higher due to the socialist heritage (DJI 2005, p.144). In both parts of Germany there were large differences between rural and urban areas. These differences were more pronounced in West Germany, where the place-to-child ratio in urban areas was 7 times higher than the one in rural areas (2002: place-to-child ratio of $2.1 \%$ in rural areas, DJI 2005, p. 145). As a consequence, informal care arrangements have always played an important role in Germany. In 2002, for example, $27.6 \%$ of all primary school-aged children were cared for by relatives, $6.6 \%$ were cared for by friends and neighbors and $0.6 \%$ were cared for by nannies. ${ }^{2}$

Prior to the expansion of $\mathrm{AD}$ schools the labor force participation rate of mothers with primary school-aged children in Germany was as high as in most other European countries. Yet, it was substantially lower than in Scandinavian countries. Focusing on 18- to 45-year-old women whose youngest child is aged 6 to 9, microcensus data from 2002 reveal that $73.7 \%$ of these mothers were in the labor force. ${ }^{3}$ Although female labor force participation rates for East and West Germany have started to converge after the German reunification (Bonin \& Euwals 2005), in 2002 there were still substantial differences between the two former parts of Germany. In East Germany the labor force participation rate of these mothers was 20 ppts higher than in West Germany. At 92.0\% it was close to the one of Scandinavian countries. Full-time employment was less common in Germany than in other countries. According to the microcensus, only $35.2 \%$ of all employed mothers whose youngest child was aged 6 to 9 were full-time employed in 2002. This low full-time employment rate was primarily driven by West German mothers. Thus, in combination with the low supply and use of institutionalized care for primary school-aged children these employment statistics suggest that the effect of $\mathrm{AD}$ primary school programs on maternal labor supply may be relatively large in Germany. ${ }^{4}$

\footnotetext{
${ }^{2}$ Own calculations based on the SOEP, 2002.

${ }^{3}$ For these figures and those that follow throughout this paragraph I rely on the calculations by Kreyenfeld \& Geisler (2006).

${ }^{4}$ This impression is reinforced by surveys which were conducted after the end of the IZBB program. One of the main reasons indicated by part-time employed mothers for not taking up full-time employment was the lack of adequate childcare for school-aged children once the school finishes (BMFSFJ 2011). Among non-employed mothers with primary school-aged children, 50\% indicated childcare as the main reason for not searching employment (Statistisches Bundesamt 2012). Among parents with school-aged children who indicated to face substantial difficulties in combining work and family life in 2011, roughly $60 \%$ suggested
} 


\subsection{The $I Z B B$ program}

To enhance the compatibility between work and family life, the German federal government launched the IZBB program in 2003. ${ }^{5}$ The main purpose of this program was the establishment and expansion of AD schools in Germany. By providing subsidies the federal government wanted to incentivize the states to invest in the formation of AD schools in order to create a demand-oriented and area-wide supply of AD schools in all states (BMBF 2003). The total investment volume of the IZBB program was about 4 billion euros. But as federal investments were made conditional upon additional investments by the states the actual investment volume was considerably higher. Federal investments were exclusively used for constructional purposes, i.e. to set up new AD schools and to restructure old AD schools. Investments by the states were mainly used to cover the personal and operating costs of AD schools.

From 2003 to 2009 IZBB investments were allocated to more than 8200 schools. Primary schools were of particular importance. More than half of the total investment volume was allocated to schools in the primary education sector (BMBF 2009). As a consequence, the share of AD primary school students has more than quadrupled since 2003. In 2009 more than $20 \%$ of all primary school students in Germany were registered for the attendance of AD school programs (KMK 2014).

In order to receive IZBB investments schools had to apply to the states which were responsible for the selection of appropriate projects. For the application the school director and school committees usually had to develop a school concept which had to be approved by the school council. Furthermore, in some states it was necessary to obtain parental consent, i.e. the parent council had to agree upon the establishment of an AD school at the school conference (BKJ 2006). As each state received a fixed amount of federal investments per year which was proportional to the total number of school students living in that state (reference year: school year 2000/01, BMBF 2003), IZBB investments were allocated to schools on a first come first served basis. As a consequence, some schools that applied for funding were not approved for funding (cf. BKJ 2006, p. 50). But due to the low number of applicants, in general, non-approval of schools does not pose a threat to my empirical strategy.

The total amount of investments allocated to primary schools when compared to secondary schools differed across states. At the beginning of the investment period most states

that better care arrangements during school holidays would help them to improve the reconciliation of work and family life (BMFSFJ 2011). Moreover, a better state support with respect to childcare costs (roughly $50 \%)$ and a closer distance to AD schools (45\%) were considered helpful policies.

${ }^{5}$ Note that the enhancement of the compatibility between work and family life was not the only objective of the IZBB program. In addition, German politicians aimed at achieving more educational and social justice. For a summary on all objectives of the IZBB program please refer to BMFSFJ (2013). 
declared particular goals (cf. BKJ 2006 and Bertelsmann Stiftung 2012). Some states focused on the primary education sector (e.g. Berlin, North Rhine-Westphalia). Other states focused on the secondary education sector (e.g. Bavaria, Baden-Württemberg, Lower-Saxony). And a third group of states restricted their investments neither to the primary nor the secondary education sector, but rather focused on schools located in areas with low socio-economic status or a high share of immigrants (e.g. Hamburg, Saxony-Anhalt). Due to these different targets there was substantial variation in the amount of IZBB investments allocated to AD primary schools across regions. Variation over time resulted from gradual implementation of the investment program.

\subsection{AD Primary Schools in Germany}

The expansion of AD schools in Germany has increased the time spent in primary schools for children that make use of AD school programs by more than 30\%, on average. Nevertheless, when compared to their peers in Anglo-American or Scandinavian countries, primary schoolaged children in Germany still tend to spend less time in AD schools. This is because AD primary schools in Germany are only obliged to provide an AD program which comprises seven hours per day on at least three days per week (KMK 2014). Although in several states requirements for $\mathrm{AD}$ schools at the primary level tend to be stricter and some schools voluntarily provide a more comprehensive AD program, it is possible that AD primary school programs have only insufficiently increased the time spent in school. If this was the case, maternal labor supply responses would be limited and I would expect them to mainly prevail at the extensive margin.

There are three additional differences between AD primary schools in Germany and those in other countries which have to be taken into account when choosing the empirical strategy and interpreting the estimation results. First, in Germany half-day schools and AD schools coexist. Unlike in other countries it is, however, not the place of living that determines the type of school a child attends. Instead, in Germany parents decide according to their

preferences upon participation and non-participation in AD primary school programs of their child. This is because in Germany roughly $90 \%$ of all AD schools in the primary education sector are organized as open AD schools (KMK 2014), i.e. the AD school program is made available to parents on a voluntary basis. Moreover, in many states parents' choices are not limited by school districts if parents are willing to make use of an AD school program, but the school which is closest to the place of living does not provide such a program. As a consequence, selection into AD primary school programs has to be considered by the empirical strategy.

Second, the teaching curricula of AD primary schools in Germany did often not schedule 
extra lessons. Instead, many schools increased their supply of social and cultural activities. Daily homework assistance became a constituent component of the curricula in many schools. Therefore, AD primary schools were often used by parents for other reasons than maternal employment (BMFSFJ 2011, p. 21). But as the additional offers were often not directly provided by schools but rather in cooperation with some external associations (e.g. sports clubs, music schools), little is known about the quality of these schools. Börner et al. (2010) find, for example, that mothers with better social, cultural and economic resources were more likely to critically oppose AD primary schools. One possible explanation for this attitude could be that AD schools often hired staff who did not hold a pedagogical degree to respond to the increased personal demands.

Third, in Germany costs of AD schools (if the AD option is taken) are relatively low when compared to other countries. They tend to differ a lot across states, municipalities and school authorities and often gradually increase with parental income. Besides the tuition fee, parents are charged a fee for lunch in school and, sometimes, a fee for some of the extracurricular activities. In total, the costs of AD school programs range from $€ 30$ to $€ 150$ per month (cf. Dohmen \& Himpele 2006). These low costs render AD school programs particularly attractive for socio-economically disadvantaged families. Through the use of AD school programs their children get access to social and cultural activities they might not have had access to otherwise.

\section{Data}

The main data for this study were drawn from the SOEP. The SOEP is a representative longitudinal study of private households in Germany, which was launched in 1984. Originally, the survey included West German households only. After the German reunification a representative sample of East German households was added. Interviews are conducted on an annual basis and in 2013 more than 25,000 persons in more than 13,000 households were interviewed. The survey includes questions on demographics, household composition, educational outcomes and labor market characteristics of the respondent. Information on the attendance of AD school programs is collected since $1995 .^{6}$

To obtain data on AD schools and the IZBB program, I make use of two additional administrative data sets which are merged by location. The Standing Conference of Ministers of Education and Cultural Affairs of the Länder (in German: Kultusministerkonferenz = KMK) has reported the share of AD primary schools among all primary schools and the

\footnotetext{
${ }^{6}$ For further information on the survey content and the sampling structure of the SOEP please refer to Wagner et al. (2007).
} 
share of AD primary school students among all primary school students for each state in Germany since 2002 (KMK 2014). Data on the number of (AD) schools and the number of (AD) school students were collected at the beginning of each school year and thus reflect the situation in October of a given year. ${ }^{7}$ For some states data on the total number of students at the primary level was missing. To compute the AD school student shares for these states, information on the number of students at the primary level was elicited from the German Federal Statistical Office (Statistisches Bundesamt 2013). The main results remain, however, qualitatively unchanged if I drop mothers who are living in states with missing information.

Information on IZBB investments was collected by the Social Pedagogical Institute of the Technical University of Applied Science in Cologne (SPI NRW 2010). Commissioned by the Federal Ministry of Education and Research, this institution has gathered detailed information on all schools in Germany that received IZBB investments during the investment period. Besides the name, the type and the location of a school, the data set provides information on the years of funding for a particular school, the type of funding (e.g. funding used to set up new AD schools vs. funding used to restructure and improve the quality of old AD schools), and the amount of funding allocated to that school in a given year. This information is used and collapsed at the county level to obtain county level data on the number of primary schools that received IZBB investments in a given year and the total amount of IZBB investments allocated to primary schools in a county in a given year. For schools in Thuringia only information on the years of funding and the total amount of funding allocated to each school during the investment period are available. To obtain yearly data on the amount of IZBB investments allocated to each school in a given year, I assume that that the total amount of funding allocated to a school was distributed equally across those years which were indicated for IZBB investment receipt. Robustness checks show, however, that my results are robust to this assumption.

Finally, I supplement my data with county level employment data. The female regional unemployment rate was retrieved from the Federal Institute for Research on Building, Urban Affairs and Spatial Development.

The main sample which is used throughout the analysis focuses on mothers in Germany who live in a private household between 2003 and 2009 and have at least one primary schoolaged child in the household. For the sake of comparison across states, I only consider mothers whose children are aged 5 to 10 when attending primary school. Due to the unavailability of yearly data on schools that received IZBB investments in Bavaria, I have to exclude Bavarian

\footnotetext{
${ }^{7}$ As parents have to register their child for $\mathrm{AD}$ school programs at the beginning of a school year or school term, I assume that the share of AD primary schools and the share of AD primary school students are constant within a school year when merging these data with my main data set at the state level.
} 
mothers from my analysis. To ensure that mothers belong to the working age population, I drop 4 mothers from my sample who are younger than 15 or older than 64 . Furthermore, I discard 132 mothers who are self-employed or in education. Both groups of mothers tend to be more flexible with respect to their working hours and the choice of their working place, thus facing less difficulties in combining work and family life. Finally, I drop 194 mothers with missing information in one of the dependent or explanatory variables. ${ }^{8}$ After the deletion of observations with missing values the remaining sample encompasses 1,763 mothers with 5,010 mother-year-observations.

For the descriptive analyses two additional samples are drawn. The first sample also focuses on mothers as the main unit of analysis. The second sample focuses on the children of these mothers instead. I apply the same sample restrictions as for my main sample, except that I now expand the time period to also cover some pre- and post-investment years. The extended time period covers all years between 1997 and 2013. The first sample (sample of mothers) is used to analyze the maternal use of AD primary school programs and maternal employment over time. Based on a sample of 11,586 mother-year-observations I compute both maternal employment shares and the share of mothers who make use of AD primary school programs. The estimates for each year are based on at least 500 observations. ${ }^{9}$

The second sample (sample of children) is used to analyze whether or not AD schools have crowded out alternative types of care for primary school-aged children. I distinguish between 4 types of care: AD schools, horts ${ }^{10}$, others types of paid care (e.g. child minder), and unpaid care (e.g. relatives or friends). As in the SOEP information on paid and unpaid care was not gathered in 1998 and 2003, I am not able to compute the share of primary schoolaged children that make use of these types of care, respectively, for these years. Moreover, information on the collection of care variables was incomplete for some children. Therefore, I drop 488 child-year-observations, thus disregarding some children of those mothers that were included in the first sample used for descriptive purposes. In total, I have 12,877 child-year-observations and base my estimations on at least 532 observations per year.

\footnotetext{
${ }^{8}$ These numbers translate into the loss of 4 (working age population), 389 (exclusion of mothers who are self-employed or in education), and 459 (exclusion of mothers with missing information) mother-yearobservations.

${ }^{9}$ By construction the estimates for the yearly employment shares are based on fewer observations per year if I compute the employment shares separately for mothers who make use of AD primary school programs and mothers who do not make use of these programs.

${ }^{10} \mathrm{~A}$ hort is a specific type of after-school care center in Germany. It is run by the institution of child and youth welfare and mainly attended by primary school students up to grade 4 . Despite horts are distinct from AD schools, they often closely cooperate with schools at the primary education level. Therefore, I separately show the share of primary school-aged children making use of horts and other types of paid care, respectively.
} 


\section{Empirical Strategy}

In Germany the impact of $\mathrm{AD}$ primary school programs on maternal labor supply is likely distorted by two types of selection: selection at the school level (AD school selectivity) and selection induced by parents (selection into AD primary school programs). To address this selection, I estimate bivariate probit models and exploit exogenous variation in the allocation of IZBB investments to AD primary schools across counties and over time to identify my models. This section discusses the selection problem and presents my empirical models and my identification strategy.

\subsection{AD School Selectivity and Selection into AD Primary School Programs}

In Germany public schools must virtually accept all students who live within their attendance boundaries. In general, it is thus very difficult to exclude students from their attendance. As AD schools, however, were relatively rare at the beginning of the investment period, these schools were allowed to exclude students if capacity constraints of a school were reached. In such a case, priority was given to particular types of families: Single-parent families, dual-earner families, and socially or economically disadvantaged families often had a higher chance of being accepted. But selection criteria differed among schools and relatively little is known about the choices made within each school. Selectivity of AD schools could thus lead to spurious correlation between the indicator for the use of AD primary school programs and the error term in a single-equation probit for maternal (full-time) employment. In particular, I would overestimate the true effect of using AD primary school programs on maternal labor supply, if there were some unobserved maternal characteristics which were positively correlated with both the use of AD primary school programs and maternal (fulltime) employment.

Apart from selectivity of $\mathrm{AD}$ schools, selection into AD primary school programs could lead to biased estimates in a single-equation probit model for maternal (full-time) employment. In Germany parents can decide according to their preferences upon participation and non-participation in AD primary school programs of their child. Mothers with more favorable labor market characteristics and stronger work preferences may be more likely to opt for AD primary school programs. As these mothers also face a higher likelihood of being (full-time) employed, part of the AD schooling effect could be due to the way mothers se-

lect into AD primary school programs. But, in general, negative selection into AD primary school programs would also be possible. Since social and cultural activities are offered by AD schools at very low costs, mothers with more unfavorable labor market characteristics and lower work preferences may have stronger preferences for AD primary school programs. As these different types of selection may partial out each other, the presence of selection has to 
be empirically tested. In anticipation of a non-negative effect of AD primary school programs on maternal labor supply, one would be particularly concerned about positive selection.

On top of controlling for a large battery of covariates I take selection into account by estimating two bivariate probit models - one for the extensive (employed vs. non-employed) and one for the intensive margin conditional on being employed (full-time vs. part-time). Bivariate probit models explicitly incorporate the binary nature of my dependent variables and produce (full-time) employment probabilities which lie within a reasonable range of values. They rely, however, on stronger assumptions than alternative methods. In particular, the credibility of results strongly depends on the bivariate normality of the structural errors. Therefore, I report 2SLS estimates as a robustness check. The potential drawback of 2SLS, however, is that the predicted (full-time) employment probabilities may lie outside the 0-1 interval. Moreover, 2SLS estimates are less precisely estimated in the presence of selection on unobservables.

\subsection{Bivariate Probit Models}

In the following I describe the model which estimates the effect of AD primary school programs on maternal labor supply at the extensive margin. ${ }^{11}$ Let the indicator variable $E_{i t}=1$ if mother $i$ is employed in period $t$, and let $E_{i t}=0$ otherwise. Moreover, let $A D_{i t}=1$ if mother $i$ makes use of an AD primary school program in period $t$, and let $A D_{i t}=0$ otherwise. $^{12}$ The maternal choice problem is then described by the following system of latent equations:

$$
\begin{aligned}
E_{i t}^{*} & =X_{i t}^{\prime} \beta+\alpha A D_{i t}+\varepsilon_{i t} \\
A D_{i t}^{*} & =Z_{i t}^{\prime} \gamma+u_{i t},
\end{aligned}
$$

where $E_{i t}^{*}$ and $A D_{i t}^{*}$ denote the net benefits that mother $i$ receives from engaging in employment and making use of AD primary school programs in period $t$, respectively, $X_{i t}$ and $Z_{i t}$ are vectors of maternal characteristics, and $\varepsilon_{i t}$ and $u_{i t}$ are random error terms. To allow for the possibility that the unobserved determinants which affect the two maternal choices are

\footnotetext{
${ }^{11}$ To obtain the model for maternal labor supply at the intensive margin, the variable $E$ only needs to be replaced by its counterpart on the intensive margin, FTE. As the variable FTE is available for employed mothers only, estimated effects are conditional on maternal employment.

${ }^{12}$ For the operationalization and exact of definition of my dependent variables please refer to the next subsection.
} 
correlated, I assume that $\varepsilon_{i t}$ and $u_{i t}$ are bivariate normal distributed

$$
\left(\begin{array}{l}
\varepsilon_{i t} \\
u_{i t}
\end{array}\right) \sim B I V N(0,0,1,1, \rho) .
$$

A mother will only work if the expected net benefits of being employed are positive. Similarly, she will only make use of an AD primary school program if the expected net benefits of using this program exceed zero. Thus, I have

$$
\begin{aligned}
E_{i t} & =\mathbf{1}\left\{E_{i t}^{*}>0\right\} \\
A D_{i t} & =\mathbf{1}\left\{A D_{i t}^{*}>0\right\} .
\end{aligned}
$$

Given that both decisions are dichotomous, a mother is in one out of four possible states: If she accepts the $\mathrm{AD}$ primary school program, she can be either employed $\left(E_{i t}=1\right.$ and $\left.A D_{i t}=1\right)$ or non-employed $\left(E_{i t}=0\right.$ and $\left.A D_{i t}=1\right)$; if she declines the AD primary school program, she can be either employed $\left(E_{i t}=1\right.$ and $\left.A D_{i t}=0\right)$ or non-employed $\left(E_{i t}=0\right.$ and $\left.A D_{i t}=0\right)$. The corresponding probabilities, which can be attached to these four states, are

$$
\begin{aligned}
& \operatorname{Pr}\left(E_{i t}=1, A D_{i t}=1 \mid X_{i t}, Z_{i t}\right)=\Phi_{2}\left(X_{i t}^{\prime} \beta+\alpha, Z_{i t}^{\prime} \gamma, \rho\right) \\
& \operatorname{Pr}\left(E_{i t}=0, A D_{i t}=1 \mid X_{i t}, Z_{i t}\right)=\Phi_{2}\left(-X_{i t}^{\prime} \beta-\alpha, Z_{i t}^{\prime} \gamma,-\rho\right) \\
& \operatorname{Pr}\left(E_{i t}=1, A D_{i t}=0 \mid X_{i t}, Z_{i t}\right)=\Phi_{2}\left(X_{i t}^{\prime} \beta,-Z_{i t}^{\prime} \gamma,-\rho\right) \\
& \operatorname{Pr}\left(E_{i t}=0, A D_{i t}=0 \mid X_{i t}, Z_{i t}\right)=\Phi_{2}\left(-X_{i t}^{\prime} \beta,-Z_{i t}^{\prime} \gamma, \rho\right),
\end{aligned}
$$

where $\Phi_{2}$ denotes the cumulative density function of the bivariate standard normal distribution. Using a slightly more compact notation the likelihood contribution of mother $i$ in period $t$ is

$$
f\left(E_{i t}, A D_{i t} \mid X_{i t}, Z_{i t}\right)=\Phi_{2}\left(w_{E, i t}, w_{A D, i t}, \rho^{*}\right)
$$

where

$$
\begin{aligned}
w_{E, i t} & =\left(2 E_{i t}-1\right)\left(X_{i t}^{\prime} \beta+\alpha A D_{i t}\right) \\
w_{A D, i t} & =\left(2 A D_{i t}-1\right)\left(Z_{i t}^{\prime} \gamma\right) \\
\rho^{*} & =\left(2 E_{i t}-1\right)\left(2 A D_{i t}-1\right) \rho .
\end{aligned}
$$

Assuming independence across time and mothers the log likelihood function for the bivariate 
probit model is given by

$$
\ln L=\sum_{i=1}^{n} \sum_{t=1}^{T_{n}} \ln \Phi_{2}\left(w_{E, i t}, w_{A D, i t}, \rho^{*}\right) .
$$

But the assumption of no correlation over time is overly restrictive. Wooldridge (2010, Ch. 13.8) has shown for the random effects probit model that, under the assumption of normally distributed random effects, a pooled probit model though misspecified recovers consistent average partial effects. Therefore, he suggests to estimate pooled probit models instead of proper random effects models. Cluster-robust standard errors are required to allow for correct inference. I adopt this strategy and apply it to the bivariate probit model.

In order to achieve identification I require at least one variable in $Z_{i t}$ which is excluded from $X_{i t}$ (instrument). As the credibility of my results strongly depends on the quality of this instrument, I discuss the choice of my instrument in detail in subsection 4.4.

The main effect of interest, the average treatment effect (ATE), can be computed as the average difference between the probability that a mother would be employed if she made use of an AD primary school program and the probability that she would be employed if she did not make use of such a program. Hence, the estimator for the ATE is

$$
\widehat{A T E}=\frac{1}{\sum_{i=1}^{n} T_{n}} \sum_{i=1}^{n} \sum_{t=1}^{T_{n}}\left[\Phi\left(X_{i t}^{\prime} \hat{\beta}+\hat{\alpha}\right)-\Phi\left(X_{i t}^{\prime} \hat{\beta}\right)\right]
$$

where $\Phi$ denotes the cumulative distribution function of the standard normal distribution. I report a cluster-robust version of the standard error for the ATE which is derived using the delta method.

Under independence of the structural errors $\varepsilon_{i t}$ and $u_{i t}$, the bivariate probit model would simplify to two univariate probit models. Thus, an insignificant estimate of the correlation $\rho$ suggests that I could estimate a single-equation probit for maternal (full-time) employment to uncover the ATE. The degree of AD school selectivity and the degree of selection into AD primary school programs would then both be negligible, or, different types of selection would partial out each other. As my results reveal, however, there is substantial evidence for selection based on unobservable maternal characteristics. In both models - the model for the extensive margin and the model for the intensive margin - my estimate for $\rho$ is highly significant. The magnitude of the estimated coefficient indicates a mid to large correlation between the structural errors $\varepsilon_{i t}$ and $u_{i t}$. Thus, single-equation probit models would show biased estimates of the ATE. 


\subsection{Operationalization of the Dependent Variables}

The main variables of interest which are used throughout my analysis are two indicators for the maternal employment status (extensive vs. intensive margin) and one indicator for the maternal use of AD primary school programs. To measure employment at the extensive margin, I distinguish between employed and non-employed mothers, i.e. I set the binary variable $E$ equal to one if the mother indicated to be full-time employed, part-time employed or irregularly employed (e.g. Mini-job) and equal to zero if the mother indicated to be unemployed or non-employed for other reasons. To measure employment on the intensive margin,

I differentiate between mothers who reported being full-time employed and mothers who reported being less than full-time employed, i.e. part-time employed or irregularly employed. The binary variable FTE thus measures the maternal employment status at the intensive margin conditional on maternal employment.

To construct the indicator for the maternal use of AD primary school programs, I proceed in two steps. In a first step, I use two questions from the household questionnaire to classify primary school-aged children into those making use of AD school programs and those not making use of these programs. In a second step, I use the information at the child level to generate an indicator for the use of AD primary school programs at the maternal level. As half-day schools in Germany have also started to provide programs which go beyond the education in the morning, borders between half-day schools and AD schools in Germany have become more and more blurred (Blossfeld et al. 2013). Moreover, given that $90 \%$ of all AD schools in the primary education sector are organized as open AD schools (KMK 2014), there are some students who attend an AD primary school, but do not make use of the AD school program. As a consequence, in the German context it is more meaningful to focus on the use of AD primary school programs rather than the attendance of AD primary schools.

The first question, which is used to classify children into users and non-users of AD primary school programs, provides information on the type of school or institution a child attends. The second question provides information on the time spent in this school or institution. While the first question is used to identify children who attend primary schools, the second question is exploited to distinguish between children who make use of AD school programs and those who do not make use of these programs. Due to a change in the questionnaire, however, there is a small group of children which cannot be unambiguously identified (cf. Marcus et al. 2013, 2015). Prior to 2009, parents were able to provide multiple answers to the first question if, for example, their child attended a primary school and was cared for in an after-school care center. As the second question referred to the time spent in schools and other institutions, I thus do not know for children whose parents indicated both 
primary school and after-school care center, whether "mainly $\mathrm{AD}^{13}$ " means that their child attended a primary school half-day and made use of an after-school care center or that their child attended a primary school full-day and made use of an after-school care center. ${ }^{14}$

To address this issue and to avoid the loss of observations, I classify children, who can not be unambiguously identified, as those making use of AD primary school programs. Given that this classification problem mainly concerns children in East Germany (due to the larger availability of after-school care centers in East Germany), I decided upon this strategy for two reasons: First, in East Germany AD primary school programs and after-school care centers are often used in a complementary fashion (cf. Marcus et al. 2013). Second, in East Germany after-school care centers and primary schools often closely cooperate to jointly provide an AD program. My results are, however, robust to alternative strategies which either classify children, who can not be unambiguously identified, as those not making use of AD primary school programs or drop mothers of these children.

Some mothers in my data set have multiple children in primary school some of whom make use of AD primary school programs and some of whom do not. As information on the use of AD primary school programs was gathered at the child level, I need to aggregate this information at the maternal level. In my main specification I set the indicator for the use of $\mathrm{AD}$ primary school programs on the maternal level equal to one if at least one primary school-aged child in the household made use of the AD school program and zero else. As a robustness check I use two alternative strategies. First, I set this indicator equal to one if all primary school-aged children in the household made use of the AD school program and zero else. Second, I drop maternal observations if multiple primary school-aged children in the household were registered and hereupon use a one-to-one mapping to obtain the information on the use of AD primary school programs at the maternal level.

The SOEP enables me to control for a large battery of covariates. In my main specification I control for the following maternal characteristics: age, migration background, marital status, education, experience, experience squared, the number of children in the household, the presence of young children in the household, deflated need-weighted monthly non-wife net household income, the size of the agglomeration, and an indicator for mothers in East Germany. Moreover, all my regression include state and year fixed effects. To explore treatment effect heterogeneity and to check the sensitivity of my results to the inclusion of additional sets of control variables, I consider some additional variables. A detailed

\footnotetext{
${ }^{13}$ Regarding the time spent in schools and institutions parents had to choose one among the following three answers: mainly in the morning, mainly in the afternoon, mainly AD.

${ }^{14}$ Marcus et al. (2013) show that despite this ambiguity official AD primary school student shares are replicated quite well with SOEP data.
} 


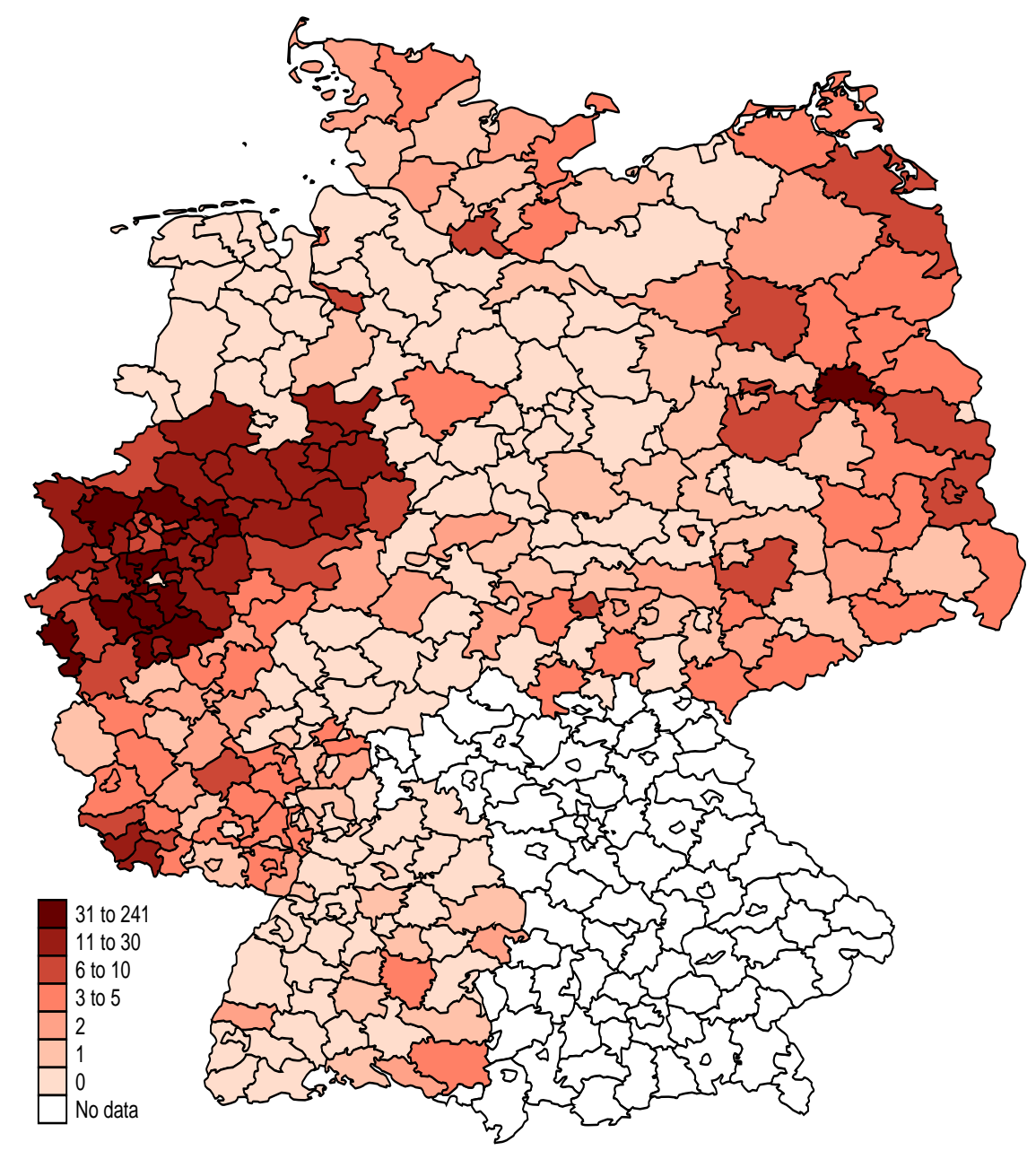

Figure 2. Number of Primary Schools Receiving IZBB Investments (County-Level), GERMANY 2005

Source: SPI NRW (2010), own representation.

description of all variables used throughout my analyses is provided in Table A.1 in the appendix.

\subsection{Identification}

Initially, I use the yearly number of primary schools receiving IZBB investments in a county as my instrument (main specification). As my regressions include both state and year fixed effects, it is important to have sufficient variation in the instrument. Figure 2 illustrates some of this variation. In 2005, for example, there was substantial variation in the number of primary schools receiving IZBB investments across counties. Even within the same state differences among counties were sizable. But due to the different targets of states, these differences were smaller than differences among counties across states. As expected states which focused on the primary education sector (e.g. Berlin and North Rhine-Westphalia) 
allocated IZBB investments to much more primary schools than states which focused on the secondary education sector (e.g. Baden-Württemberg and Lower-Saxony).

Subsequently, I use two additional instruments. The yearly amount of IZBB investments allocated to primary schools in a county is one of these instruments. Like my main instrument, this instrument uses exogenous variation in the allocation of IZBB investments. The advantage of this instrument over my main instrument is that it better captures the increase in availability and quality of AD primary schools. For example, if the correlation between the number of primary schools receiving IZBB investments and the amount of IZBB investments allocated to primary schools is negative for some counties, this instrument will be more informative than my main instrument; it will more strongly correlate with the maternal use of AD primary school programs.

But the advantage of this instrument over my main instrument comes at some costs. Due to the unavailability of yearly data on the amount of IZBB investments allocated to primary schools in Thuringia, I had to impute the values of this variable for Thuringian primary schools using yearly data on the investment receipt and the total amount of investments allocated to primary schools during the investment period. More specifically, for each school I imputed the missing values for years with positive investments using the average amount of IZBB investments allocated to this school. While I am able to correctly identify the years with zero investments, I likely over- and underestimate the amount of investment in those years that exhibit positive investments. That is, my instrument is subject to measurement error, which may lead to severely biased estimates in some specifications. To avoid this bias, I can rely on an alternative strategy and drop observations from Thuringia. The smaller sample size, however, results in a loss of precision. Given this trade-off I decided upon using both strategies when testing the sensitivity of my estimation results to the use of this alternative instrument.

The yearly share of AD primary schools among all primary schools in a state is the third instrument used to check the robustness of my findings. The advantage of this instrument over the former two instruments is that it directly measures the regional availability of AD primary schools. Moreover, it implicitly accounts for both IZBB investments and other than IZBB investments which were used to expand AD primary schools in Germany. Hence, exploiting slightly different sources of exogenous variation, this instrument can be used in addition to my main instrument. This leads to a model which is overidentified and then can be tested to gain some knowledge on the validity of my instruments.

The main underlying economic idea of my instruments is as follows. IZBB investments were either used to set up new AD schools or to restructure old AD schools. While the former improves access to AD primary schools and reduces the costs associated with $\mathrm{AD}$ 
primary schooling, the latter increases the quality of existing AD primary schools. As both the costs and the quality of care are important determinants of the demand for childcare (e.g. Blau \& Robins 1988, Blau \& Hagy 1998), an increase in the number or amount of IZBB investments allocated to primary schools should positively affect the probability of mothers to make use of AD primary school programs. The magnitude of effects, however, depends on the overall availability of AD primary schools. It tends to be smaller if the share of AD primary schools among all primary schools is lower (cf. Cascio et al. 2015).

A valid instrument has to fulfill two properties: First, it must be a determinant of the decision to make use of AD primary school programs (instrument relevance). Second, it must not be a determinant of maternal (full-time) employment, i.e. it must be uncorrelated with the error term in the (full-time) employment equation (instrument exogeneity). Based on my estimation results the first property can be tested. Thus, the credibility of my results hinges on the second property. The major concern with regard to this property is that parents, in particular mothers, were able to influence the allocation of IZBB investments. Counties whose primary schools received many IZBB investments would then systematically differ from counties whose primary schools received no or very few IZBB investments. If these differences were linked to the maternal employment decision, my instrument would be correlated with the structural error in the (full-time) employment equation, thus invalidating my instrument. Although I am not able to prove for sure that my instruments are exogenous, I argue that mothers were very unlikely to influence the allocation of IZBB investments.

There are four main arguments for the exogeneity of the IZBB instruments. First, the amount of IZBB investments allocated to each state in each year was proportional to the total number of school students who were living in this state in the school year 2001/2002, i.e. the amount of IZBB investments allocated to each state was predetermined. Thus, mothers were not able to influence the allocation of IZBB investments across states. Second, states declared a particular focus at the beginning of the investment period. Due to this focus, mothers were not able to influence the allocation of investments to primary schools within those states that decided to focus on the expansion of AD schools in the secondary education sector ex-ante. Third, the allocation of IZBB investments within states was based on a twostep decision-making process. In a first step, schools decided to apply for investments and, in a second step, states selected some schools among the applicants. Because of the sequentiality of decisions, the state eventually decided on the allocation of investments. Fourth, because of the low acceptance of AD school programs (cf. Hagemann 2009) and the high social costs of using such programs it is very unlikely that mothers promoted a school's application. Moreover, as AD primary school programs were made available on a voluntary basis at essentially zero costs, it is also very unlikely that mothers opposed a school's application. 
To further strengthen the credibility of my instruments, I compared mothers who were living in counties whose primary schools received IZBB investments with mothers who were living in counties whose primary schools did not receive these investments. I focused on three maternal characteristics which are of particular importance for the maternal employment decision and may be closely linked to some of the unobservable maternal characteristics: education, labor market experience, and work preferences. Based on simple ordinary least squares (OLS) regressions with clustered standard errors at the maternal level and t-tests, I find no evidence for a non-random allocation of IZBB investments. Mothers who were living in counties whose primary schools received IZBB investments neither were better educated (t-statistic: 1.17) nor had more labor market experience (t-statistic: 1.44). Moreover, these mothers did not exhibit stronger work preferences (t-statistic: 0.42 , if dropping mothers with missing information on work preferences).

Another concern would be structural and institutional differences between counties that received IZBB investments and counties that did not receive these investments. If these differences were linked to the maternal employment decision, mothers could be more likely to work for other reasons than controlled for by the researcher. To address this concern, I used data from the Federal Institute for Research on Building, Urban Affairs and Spatial Development. ${ }^{15}$ Again based on simple OLS regressions with clustered standard errors I tested for differences between these two groups of counties. My results suggest that counties that received IZBB investments which were allocated to primary schools exhibited more unfavorable rather than more favorable institutional and structural characteristic; they had significantly lower childcare coverage shares for children aged 0 to 3 and children aged 3 to 6 , respectively, and significantly lower female employment and labor force participation rates. Exclusively, a comparison of the female part-time employment rates suggests the opposite. ${ }^{16}$

In addition, I also performed a placebo test based on a sample of childless women. The reduced form probit and linear probability estimates are close to zero and insignificant, independent of which IZBB instrument is used. This suggests that potential effects are unlikely driven by differences between counties that received many or high IZBB investments and counties that received few or low IZBB investments. Along with the other ex-ante tests this strengthens the credibility of my identification strategy. Yet, I recognize that the exogeneity assumption is not testable.

\footnotetext{
${ }^{15}$ Note that for some indicators data at the county level were only available after 2003.

${ }^{16}$ I included the female part-time employment rate at the county level in both labor supply models. For the extensive margin model it turned out to be insignificant. For the intensive margin model it turned out to be significant in the employment equation. But as the ATE remained unaffected, I do not control for the female part-time employment rate in my main specification.
} 


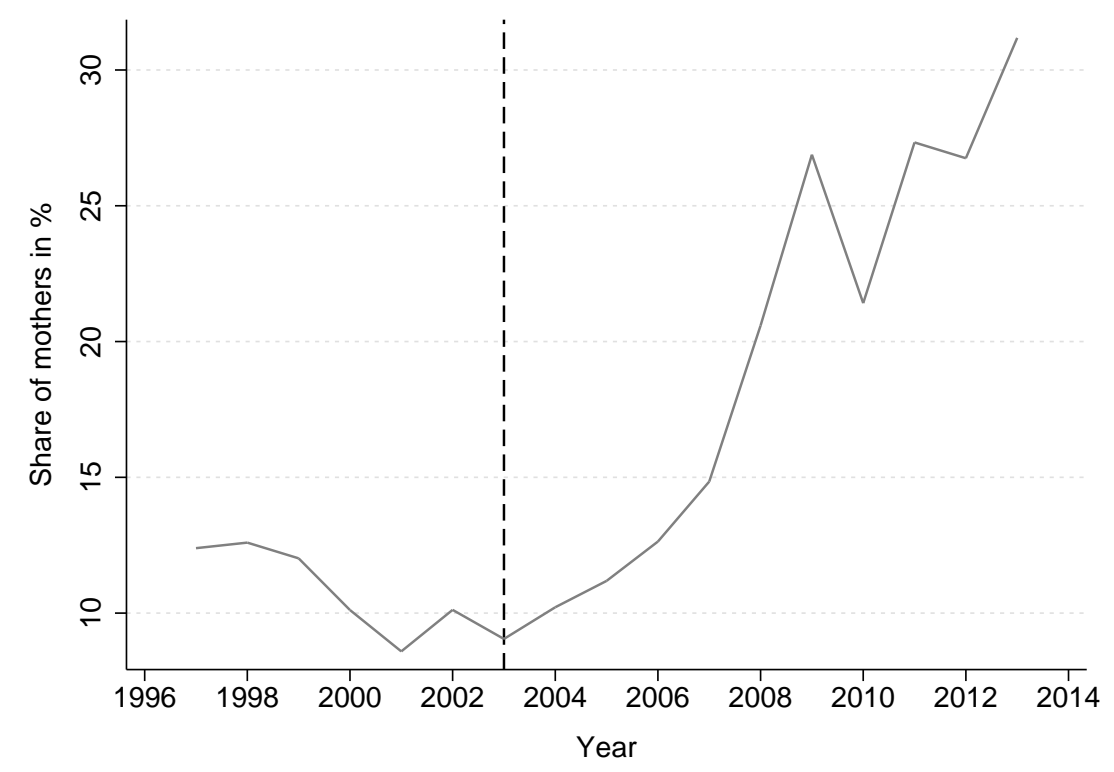

Figure 3. Maternal Use of AD Primary School Programs, Germany (1997 - 2013)

Notes: This figure shows the share of mothers with primary school-aged children in Germany who make use of an AD primary school program for at least one primary school-aged child in the household. The sample encompasses 11,586 mother-year-observations. It excludes Bavarian and/or self-employed mothers, mothers who are in education and/or do not belong to the working age population, and mothers who have missing information in one of the dependent or explanatory variables.

Source: SOEPv30 (1997-2013), own calculations.

\section{Results}

This section presents my main findings. Before turning to the discussion of my main estimation results, I present some descriptive evidence on the potential effect of AD primary school programs on maternal labor supply. In particular, I analyze the share of mothers with primary school-aged children who make use of AD primary school programs and who are employed, respectively, and the share of employed mothers with primary school-aged children who are engaged in full-time employment over time. Moreover, I investigate whether AD primary schools have crowded out alternative types of care for primary school-aged children and present summary statistics by maternal use of AD primary school programs.

\subsection{Descriptive Results}

Figure 3 depicts the share of mothers with primary school-aged children in Germany (excluding Bavaria) who make use of an AD primary school program for at least one primary school-aged child in the household. I focus on the period from 1997 to 2013 and apply the 
same sample restrictions as for my main regression sample. ${ }^{17}$ As this figure illustrates the expansion of AD primary schools in Germany has led to a sharp increase in the share of mothers who make use of AD primary school programs.

Prior to 2003 relatively few mothers made use of AD primary school programs. Only 10 to $12 \%$ of all mothers with primary school-aged children made use of this program for at least one primary school-aged child in the household. The majority of these mothers was living in East Germany, where due to the socialist heritage AD primary schools were more widespread. After the launch of the IZBB program in 2003, the use of AD primary school programs started to increase markedly. Until the end of the IZBB program this share more than doubled (roughly $26 \%$ in 2009). With the accompanying program "Ideas that go beyond! Learning AD" (in German: Ideen für mehr! Ganztägig lernen) the Federal Ministry of Education and Research has continued to promote the formation of AD schools in Germany with 4.3 million euros per year. Therefore, the share of mothers with primary school-aged children who make use of AD primary school programs continued to increase even after the end of the IZBB program.

The share of mothers with primary school-aged children who make use of AD primary schools programs only increased slightly during the first three years of the IZBB program (roughly 5 ppts). The main reason is that the majority of investments were used to set up new AD schools. As the construction of new AD schools was relatively time-consuming and additional staff had to be hired, schools were not able to provide the AD program immediately, leading to this delayed response in the use of $\mathrm{AD}$ school programs. One additional explanation for this delayed response is the low acceptance of AD school programs at the beginning of the IZBB period (Hagemann 2009, Augustin-Dittmann 2010). Only towards the end of the IZBB period attitudes towards AD schools started to change (Augustin-Dittmann 2010).

Figure 4 depicts the share of employed mothers among all mothers with primary schoolaged children in Germany who i) make use of an AD primary school program for at least one primary school-aged child in the household and ii) do not make use of this program for any of their primary school-aged children. Again I focus on the period from 1997 to 2013 and apply the same sample restrictions as for my main regression sample. ${ }^{18}$ This figure provides

\footnotetext{
${ }^{17}$ The figure remains basically unchanged if I use the full sample of mothers instead. Only if I drop mothers from Bavaria the share of mothers with primary school-aged children who make use of AD primary school programs is slightly higher after 2004. This can be explained by the fact that Bavaria has mainly focused on the expansion of AD schools in the secondary education sector during the IZBB investment period. Therefore, the share of mothers who make use of AD primary school programs is slightly lower in Bavaria. There is no evidence for bias due to item non-response.

${ }^{18}$ This figure changes slightly, if I use the full sample of mothers instead. By construction the maternal
} 


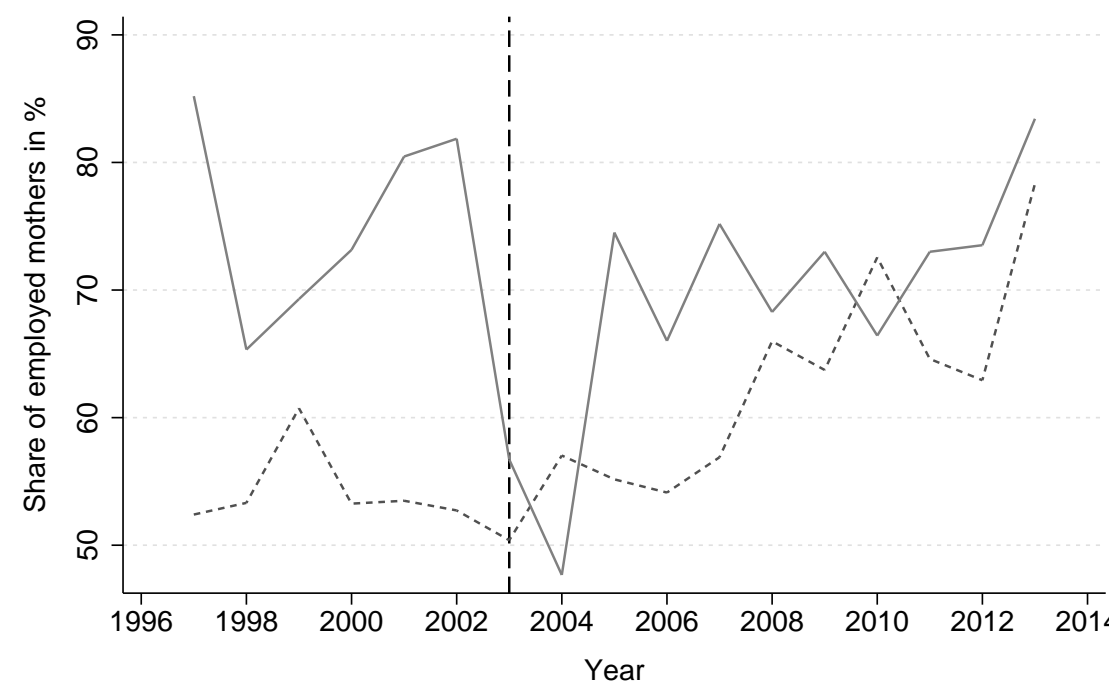

Use of AD school program -...... No use of AD school program

Figure 4. Maternal Employment by Maternal Use of AD Primary School Programs, Germany (1997 - 2013)

Notes: This figure shows the share of employed mothers among all mothers with primary school-aged children in Germany who i) make use of an AD primary school program for at least one primary school-aged child in the household and ii) do not make use of this program for any of their primary school-aged children. The sample of mothers corresponds to the one of Figure 3.

Source: SOEPv30 (1997-2013), own calculations.

first evidence for a possibly positive effect of $\mathrm{AD}$ primary school programs on maternal labor supply. In general, mothers who make use of AD primary school programs are much more likely to be employed when compared to their counterparts who do not make use of these programs. $^{19}$

But throughout the IZBB period the employment shares of the two groups of mothers started to converge. This convergence in employment shares suggests a negative selection into AD school programs: Mothers who would have been non-employed if they were not making use of AD primary school programs, started to make use of these programs. Yet, not all mothers who made use of the newly available offer engaged in employment. In particular, the share of mothers who decided upon non-employment has increased among mothers who decided to use this newly available offer. This negative selection into AD primary school

employment shares are 1 to 3 ppts higher, as I exclude self-employed mothers from my sample. Again there is no evidence for bias due to item non-response.

${ }^{19}$ The estimates for the employment shares of mothers making use of AD primary school programs preinvestment and at the beginning of the investment period (until 2006), are based on less than 100 observations each. This explains why the estimated employment share for these mothers is relatively volatile. 


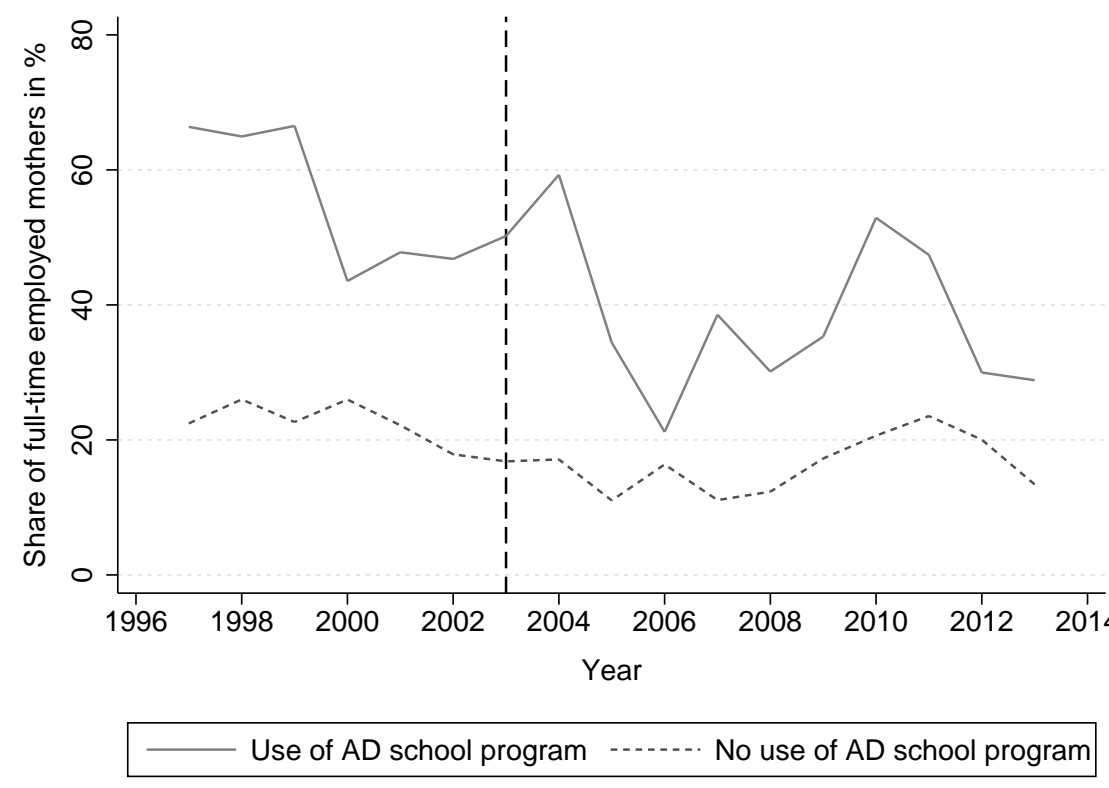

Figure 5. Maternal Full-Time Employment by Maternal Use of AD Primary School Programs, Germany (1997 - 2013)

Notes: This figure shows the share of full-time employed mothers among all employed mothers with primary school-aged children in Germany who i) make use of an AD primary school program for at least one primary school-aged child in the household and ii) do not make use of this program for any of their primary schoolaged children. The sample of mothers corresponds to the one of Figures 3 and 4, except that it excludes non-employed mothers. Estimations are based on 6,982 mother-year-observations.

Source: SOEPv30 (1997-2013), own calculations.

programs is consistent with Börner et al. (2010) who find that parents use AD primary school programs for many reasons other than maternal employment. Moreover, it is also consistent with an increasing acceptance of AD school programs; the share of mothers who have to make use of these programs because of employment tends to decrease.

Figure 5 depicts the share of full-time employed mothers among all employed mothers with primary school-aged children in Germany who i) make use of an AD primary school program for at least one primary school-aged child in the household and ii) do not make use of this program for any of their primary school-aged children. This figure shows that the use of AD primary school programs can be positively associated with maternal full-time employment. On average, employed mothers with primary school-aged children who make use of AD primary school programs were more than twice as likely to be full-time when compared to their counterparts who do not make use of these programs. But the share of full-time employed mothers among employed mothers who use AD primary school programs has declined over time. In combination with Figure 4, this decline suggests a composition effect - mothers who engaged in employment and made use of AD primary school programs 


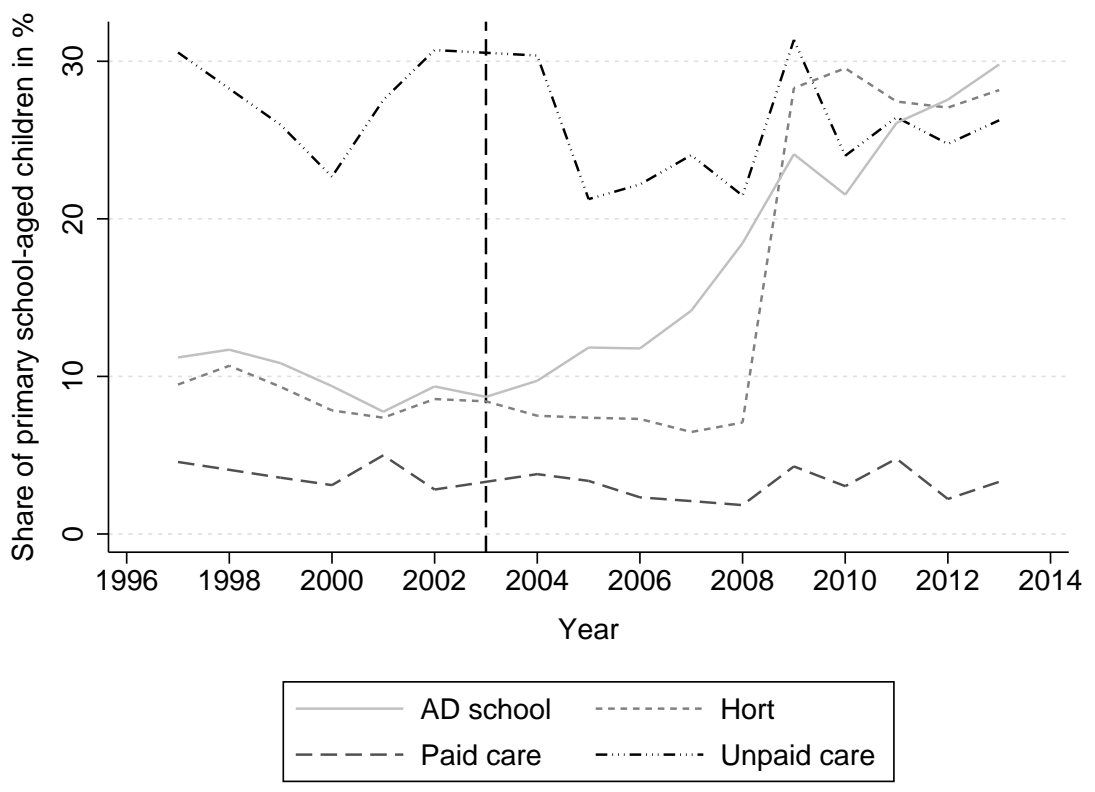

Figure 6. Use of Alternative Types of Care, Germany (1997 - 2013)

Notes: This figure shows the shares of primary school-aged children in Germany who make use of AD primary school programs, after-school care centers (hort), alternative forms of paid care, and unpaid care, respectively. Shares do not add to $100 \%$, as multiple answers were possible and some children were cared for by their parents only. The sample encompasses 12,877 child-year-observations. It excludes children of Bavarian and/or self-employed mothers, mothers who are in education and/or do not belong to the working age population, and mothers who have missing information in one of the dependent or explanatory variables. Moreover, it disregards children with missing information in one of the childcare variables.

Source: SOEPv30 (1997-2013), own calculations.

because of the lower costs associated with AD primary schooling, engaged in part-time rather than full-time employment. This finding is again consistent with Börner et al. (2010).

To summarize, these figures are suggestive for a positive effect of AD primary school programs on maternal labor supply. Yet, there are many confounding factors which are not controlled for. To learn about the potential size of the ATE, I investigate whether AD primary schools have crowded out alternative types of care for primary school-aged children next. As an analysis on the maternal level can hide important data patterns, I focus on primary school-aged children rather than their mothers throughout this analysis. Moreover, I present summary statistics by maternal use of $\mathrm{AD}$ primary school programs. The latter gives us a feeling of how much of the observed effect is likely explained by differences in maternal characteristics. If I find evidence for crowding out or a possibly positive selection into AD primary school programs, we should expect a smaller ATE. In the extreme case, the effects of AD primary school programs on maternal labor supply may be indistinguishable from zero. 
Figure 6 depicts the shares of primary school-aged children in Germany who make use of AD primary school programs, after-school care centers (hort), alternative forms of paid care, and unpaid care, respectively. Again I focus on the period from 1997 to 2013 and apply

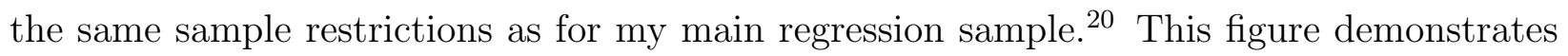
that $\mathrm{AD}$ primary school programs did not crowd out alternative types of care for primary school-aged children. While the share of primary school-aged children who make use of AD primary school programs has sharply increased after 2003, the shares of primary schoolaged children who make use of alternative types of care, respectively, have been relatively stable. The sharp increase in the share of primary school-aged children who make use of after-school care centers (hort) in 2008/09 can be explained by a change in the questionnaire in 2009. ${ }^{21}$ Hence, these results continue to support a strong positive effect of AD primary school programs on maternal labor supply.

Table 1 displays the summary statistics by maternal use of AD primary school programs. Columns 1 and 2 refer to mothers with primary school-aged children who make use of AD primary school programs, whereas columns 3 and 4 refer to mothers with primary schoolaged children who do not make use of these programs. Survey weights are used to obtain representative statistics for my specific sample of mothers. In addition, given the panel structure of my data clustered standard errors rather than standard deviations are reported. Clustered standard errors can be directly used to infer whether the differences in characteristics between mothers who make use of $\mathrm{AD}$ primary school programs and mothers who do not make use these programs are statistically significant.

Table 1 shows that, when compared to mothers who do not make use of AD primary school programs, mothers who make use of AD school programs are 10.5 ppts more likely to be employed. Moreover, if employed these mothers are roughly two and a half times more likely to be full-time employed than their counterparts who do not make use of these programs. But a comparison of the maternal and family characteristics of the two groups of mothers shows that such a simple mean-comparison would be misleading, because mothers with primary school-aged children who make use of AD primary school programs are more likely to exhibit characteristics which are positively associated with maternal labor supply.

\footnotetext{
${ }^{20} \mathrm{As}$ for the previous figures the imposed sample restrictions change the results only very little. Due to the exclusion of Bavarian children, the share of primary school-aged children who make use of AD primary school programs is 1 to 2 ppts higher after 2004 (cf. discussion of sample restrictions for Figure 3).

${ }^{21}$ Prior to 2009 information on the attendance of schools and center-based care was collected using one question only. As "after-school care center" was only one of many possible answers most of which referred to the attendance of different types of schools, it is very likely that parents were more likely to indicate the attendance of an after-school care center after the introduction of two distinct questions, one for the attendance of schools and one for the attendance of after-school care centers.
} 
Table 1. Summary Statistics by Maternal Use of AD Primary School PROGRAMS

\begin{tabular}{|c|c|c|c|c|}
\hline & \multicolumn{2}{|c|}{$\begin{array}{l}\text { Use of } \mathrm{AD} \\
\text { school program }\end{array}$} & \multicolumn{2}{|c|}{$\begin{array}{l}\text { No use of } \mathrm{AD} \\
\text { school program }\end{array}$} \\
\hline & Mean & (S.E.) & Mean & (S.E.) \\
\hline \multicolumn{5}{|l|}{ Main outcome variables } \\
\hline Employed & 0.677 & $(0.033)$ & 0.572 & $(0.018)$ \\
\hline Full-time employed $^{\mathrm{a}}$ & 0.358 & $(0.040)$ & 0.145 & $(0.014)$ \\
\hline \multicolumn{5}{|l|}{ Instruments } \\
\hline IZBB investments & 0.350 & $(0.038)$ & 0.195 & $(0.014)$ \\
\hline $\begin{array}{l}\text { Number of primary schools with IZBB } \\
\text { investments/10 }\end{array}$ & 2.9 & $(0.5)$ & 0.9 & $(0.1)$ \\
\hline $\begin{array}{l}\text { Amount of IZBB investments allocated } \\
\text { to primary schools } / 10 \text { million (in } € \text { ) }\end{array}$ & 0.371 & $(0.064)$ & 0.099 & $(0.009)$ \\
\hline Share of AD primary schools ${ }^{\mathrm{b}}$ & 0.528 & $(0.031)$ & 0.203 & $(0.009)$ \\
\hline Share of AD primary school students ${ }^{\mathrm{b}}$ & 0.284 & $(0.021)$ & 0.096 & $(0.005)$ \\
\hline \multicolumn{5}{|l|}{ Other explanatory variables } \\
\hline Age (in years) & 36.5 & $(0.4)$ & 37.9 & $(0.2)$ \\
\hline Migration background & 0.225 & $(0.034)$ & 0.315 & $(0.020)$ \\
\hline Married & 0.606 & $(0.040)$ & 0.832 & $(0.015)$ \\
\hline Education (in years) & 12.5 & $(0.2)$ & 11.9 & $(0.1)$ \\
\hline Experience (in years) & 10.1 & $(0.5)$ & 10.1 & $(0.3)$ \\
\hline Experience squared & 138.2 & $(10.3)$ & 142.5 & $(6.2)$ \\
\hline Work preference: missing & 0.020 & $(0.010)$ & 0.024 & $(0.006)$ \\
\hline Work preference: low & 0.185 & $(0.028)$ & 0.326 & $(0.018)$ \\
\hline Work preference: medium & 0.614 & $(0.035)$ & 0.523 & $(0.019)$ \\
\hline Work preference: high & 0.181 & $(0.028)$ & 0.127 & $(0.012)$ \\
\hline Number of children & 1.8 & $(0.1)$ & 2.1 & $(0.0)$ \\
\hline Young children present & 0.251 & $(0.034)$ & 0.288 & $(0.015)$ \\
\hline Use of other care: missing & 0.162 & $(0.023)$ & 0.180 & $(0.007)$ \\
\hline Use of other care: yes & 0.476 & $(0.036)$ & 0.245 & $(0.012)$ \\
\hline $\begin{array}{l}\text { Monthly non-wife net household } \\
\text { income/100 (in } €)\end{array}$ & 9.1 & $(0.5)$ & 11.0 & $(0.2)$ \\
\hline Area: rural & 0.253 & $(0.036)$ & 0.413 & $(0.020)$ \\
\hline Area: urbanized & 0.276 & $(0.039)$ & 0.343 & $(0.020)$ \\
\hline Area: urban & 0.471 & $(0.042)$ & 0.243 & $(0.017)$ \\
\hline East Germany & 0.451 & $(0.042)$ & 0.098 & $(0.009)$ \\
\hline Female unemployment rate & 0.090 & $(0.002)$ & 0.066 & $(0.001)$ \\
\hline Observations & & 93 & & 17 \\
\hline
\end{tabular}

Notes: Standard errors allow for serial correlation across observations of the same mother.

${ }^{a}$ The full-time employment means are conditional on being employed.

b Mean estimates are based on 691 (use of AD school program) and 4307 (no use of AD school program) observations, respectively.

Sources: SOEPv30 (2003-2009), KMK (2014) \& SPI NRW (2010), own calculations. 
They are slightly younger, less likely to have a migration background, less likely to be married, slightly better educated and tend to have stronger work preferences. Moreover, they have fewer children, a lower propensity to have young children, and are more likely to live in urban areas and former East Germany. ${ }^{22}$ Most of these differences in maternal characteristics are statistically significant at the $5 \%$ level. Consequently, one should expect somewhat smaller effects of AD primary school programs on maternal labor supply after controlling for these differences in observable maternal characteristics.

\subsection{Multivariate Results}

Table 2 presents my main estimation results. The bivariate probit estimates for the extensive margin model are reported in columns 1 and 2 and the bivariate probit estimates for the intensive margin model which is conditional on maternal employment are reported in columns 3 and 4. Standard errors are reported in parentheses and allow for serial correlation across observations of the same mother.

There is substantial evidence for selection based on unobservable maternal characteristics. In both models my estimate of the correlation between the two structural errors $\rho$ is highly significant. In contrast to my initial expectations, my estimate of $\rho$ is negative in the model for the extensive margin. This suggests that mothers with more favorable unobservable labor market characteristics are less likely to make use of AD primary school programs or, put differently, that mothers with stronger preferences for AD primary school programs are less likely to engage in employment. This interpretation is consistent with Börner et al. (2010) who analyze parental attitudes towards AD primary schools and explore the reasons of parents to use AD primary schools programs. Using data which were collected at open AD primary schools in North Rhine-Westphalia in 2007/08, they find that the acceptance of $\mathrm{AD}$ schools tends to be lower among better educated parents and parents with a high socio-economic status. Doubting the quality of AD schools, these parents often critically oppose AD primary schools although having higher employment probabilities. Moreover, having more financial, social and cultural resources these parents are often better able to promote their child's interest and to make use of alternative (high-quality) programs. On the contrary, parents with low socio-economic status and/or migration background often believe that their child benefits from the attendance of AD school programs, as their child gets access to a broad variety of social and cultural activities and more intensively interacts

\footnotetext{
${ }^{22}$ Rosenfeld et al. (2004) analyze the differences in work attitudes and work patterns of East and West German women. They show that, when compared to West German women, East German women have stronger work preferences, are more likely to be in the labor force and have a higher propensity of full-time employment. After the reunification, however, labor force participation rates have started to converge (Bonin \& Euwals 2005).
} 
Table 2. Bivariate Probit Estimates of Maternal Labor Supply Models

\begin{tabular}{|c|c|c|c|c|}
\hline & \multicolumn{2}{|c|}{ Extensive margin } & \multicolumn{2}{|c|}{ Intensive margin $^{\mathrm{a}}$} \\
\hline & $\begin{array}{c}\text { Use of } \mathrm{AD} \\
\text { school program }\end{array}$ & Employed & $\begin{array}{c}\text { Use of } \mathrm{AD} \\
\text { school program }\end{array}$ & $\begin{array}{l}\text { Full-time } \\
\text { employed }\end{array}$ \\
\hline Use of AD school program & & $\begin{array}{c}1.145^{* * *} \\
(0.236)\end{array}$ & & $\begin{array}{l}-0.357 \\
(0.395)\end{array}$ \\
\hline $\begin{array}{l}\text { Number of primary schools } \\
\text { with IZBB investments/10 }\end{array}$ & $\begin{array}{c}0.032^{* *} \\
(0.013)\end{array}$ & & $\begin{array}{c}0.039^{* *} \\
(0.018)\end{array}$ & \\
\hline Age (in years) & $\begin{array}{c}-0.037^{* * *} \\
(0.011)\end{array}$ & $\begin{array}{c}-0.108^{* * *} \\
(0.010)\end{array}$ & $\begin{array}{c}-0.041^{* * *} \\
(0.014)\end{array}$ & $\begin{array}{c}-0.077^{* * *} \\
(0.014)\end{array}$ \\
\hline Migration background & $\begin{array}{c}0.230^{* *} \\
(0.096)\end{array}$ & $\begin{array}{c}0.010 \\
(0.078)\end{array}$ & $\begin{array}{l}0.202^{*} \\
(0.116)\end{array}$ & $\begin{array}{c}0.509^{* * *} \\
(0.119)\end{array}$ \\
\hline Married & $\begin{array}{c}-0.338^{* * * *} \\
(0.091)\end{array}$ & $\begin{array}{c}0.359^{* * *} \\
(0.084)\end{array}$ & $\begin{array}{c}-0.349^{* * *} \\
(0.109)\end{array}$ & $\begin{array}{c}-0.256^{* *} \\
(0.118)\end{array}$ \\
\hline Education (in years) & $\begin{array}{c}0.070^{* * *} \\
(0.016)\end{array}$ & $\begin{array}{c}0.144^{* * *} \\
(0.017)\end{array}$ & $\begin{array}{c}0.076^{* * *} \\
(0.018)\end{array}$ & $\begin{array}{c}0.149^{* * *} \\
(0.022)\end{array}$ \\
\hline Experience (in years) & $\begin{array}{l}0.035^{*} \\
(0.018)\end{array}$ & $\begin{array}{c}0.235^{* * *} \\
(0.017)\end{array}$ & $\begin{array}{c}0.006 \\
(0.028)\end{array}$ & $\begin{array}{c}0.071^{* * *} \\
(0.027)\end{array}$ \\
\hline Experience squared & $\begin{array}{l}-0.001 \\
(0.001)\end{array}$ & $\begin{array}{c}-0.003^{* * *} \\
(0.001)\end{array}$ & $\begin{array}{c}0.000 \\
(0.001)\end{array}$ & $\begin{array}{c}0.000 \\
(0.001)\end{array}$ \\
\hline Number of children & $\begin{array}{c}-0.176^{* * *} \\
(0.054)\end{array}$ & $\begin{array}{c}0.022 \\
(0.041)\end{array}$ & $\begin{array}{c}-0.320^{* * *} \\
(0.076)\end{array}$ & $\begin{array}{l}-0.154^{*} \\
(0.081)\end{array}$ \\
\hline Young children present & $\begin{array}{c}0.116 \\
(0.085)\end{array}$ & $\begin{array}{c}-0.676^{* * *} \\
(0.063)\end{array}$ & $\begin{array}{c}0.324^{* * *} \\
(0.113)\end{array}$ & $\begin{array}{l}-0.059 \\
(0.111)\end{array}$ \\
\hline $\begin{array}{l}\text { Monthly non-wife net } \\
\text { household income/100 }\end{array}$ & $\begin{array}{c}-0.024^{* * *} \\
(0.006)\end{array}$ & $\begin{array}{c}-0.035^{* * *} \\
(0.006)\end{array}$ & $\begin{array}{c}-0.018^{* *} \\
(0.007)\end{array}$ & $\begin{array}{c}-0.058^{* * *} \\
(0.010)\end{array}$ \\
\hline Area: urbanized & $\begin{array}{c}0.327^{* * *} \\
(0.092)\end{array}$ & $\begin{array}{l}-0.084 \\
(0.076)\end{array}$ & $\begin{array}{c}0.279^{* *} \\
(0.113)\end{array}$ & $\begin{array}{c}0.096 \\
(0.114)\end{array}$ \\
\hline Area: urban & $\begin{array}{c}0.667^{* * * *} \\
(0.097)\end{array}$ & $\begin{array}{l}-0.177^{*} \\
(0.095)\end{array}$ & $\begin{array}{c}0.729^{* * *} * \\
(0.120)\end{array}$ & $\begin{array}{c}0.345^{* *} \\
(0.141)\end{array}$ \\
\hline East Germany & $\begin{array}{c}1.259^{* * *} \\
(0.296)\end{array}$ & $\begin{array}{l}-0.405 \\
(0.273)\end{array}$ & $\begin{array}{c}1.182^{* * *} \\
(0.382)\end{array}$ & $\begin{array}{l}-0.111 \\
(0.476)\end{array}$ \\
\hline$\rho$ & $\begin{array}{r}-0.540^{*} \\
(0.132\end{array}$ & & $\begin{array}{r}0.420^{\circ} \\
(0.215\end{array}$ & \\
\hline State FE & Yes & & Yes & \\
\hline Year FE & Yes & & Yes & \\
\hline ATE & $\begin{array}{r}0.259^{* *} \\
(0.047)\end{array}$ & & $\begin{array}{l}-0.07 \\
(0.075\end{array}$ & \\
\hline Value of log likelihood & -3638.4 & & -2135.7 & \\
\hline Observations & 5010 & & 3047 & \\
\hline
\end{tabular}

Notes: Coefficient estimates. Models additionally include a constant. Standard errors that allow for serial correlation across observations of the same mother are reported in parentheses. ${ }^{a}$ Bivariate probit estimates for the intensive margin are conditional on maternal employment. $* \mathrm{p}<0.1 * * \mathrm{p}<0.05 * * * \mathrm{p}<0.01$.

Sources: SOEPv30 (2003-2009) \& SPI NRW (2010), own estimates. 
with peers (Börner et al. 2010). These parents, however, often exhibit lower employment probabilities which would suggest a negative selection into AD primary school programs.

The estimate of $\rho$ is positive in the model for the intensive margin. To understand the reversed correlation pattern of the unobservable factors that affect both maternal full-time employment and maternal use of AD primary school programs, it is important to see that all my estimates for the intensive margin are conditional on maternal employment, i.e. I focus on a very selective sample of mothers. Within the group of employed mothers, it is very likely that differences in work preferences explain the positive correlation between the unobserved factors that affect both maternal decisions. When compared to part-time employed mothers, full-time employed mothers exhibit much stronger work preferences. Moreover, they tend to have a higher demand for childcare, because they spent more time on the labor market than part-time employed mothers. As it is more difficult to arrange family care for a full day, full-time employed mothers also have a higher likelihood of using paid and public care arrangements. Thus, even if full-time employed mothers were to more strongly oppose AD primary schools, they would eventually use AD primary school programs more often because of their stronger work preferences. ${ }^{23}$

Next, turning to the effect of my instrument on the maternal decision to make use of AD primary school programs (2nd row columns 1 and 3, respectively), my estimates indicate for both models a significantly positive effect. If IZBB investments are allocated to 10 additional primary schools in the county of residence, the probability of mothers to make use of AD primary school programs will increase by 0.5 ppts, on average. For employed mothers the effect of my instrument is of similar magnitude, leading to a 0.6 ppts increase of the corresponding probability. Although this effect seems to be small when compared to the effects of other covariates, it is sizable given that initially only $10 \%$ of all mothers with primary school-aged children made use of AD primary school programs. Moreover, considering that the magnitude of the effect should diminish as the share of AD primary schools increases, the size of the effect is plausible.

With respect to the ATE my bivariate probit estimates suggest that AD primary school programs positively affect maternal labor supply at the extensive margin, but have no effect on maternal labor supply at the intensive margin (1st row columns 2 and 4, respectively). After controlling for selection, mothers with primary school-aged children in Germany (excluding Bavaria) who make use of AD primary school programs have, on average, a 26 ppts higher likelihood of being employed than their counterparts who do not make use of these

\footnotetext{
${ }^{23}$ As full-time employment is very rare in Germany, this positive correlation may be relatively weak in the full sample of mothers which includes non-employed mothers with primary school-aged children.
} 
programs. For employed mothers my bivariate probit estimates suggest a negative, albeit insignificant effect of AD primary school programs on the full-time probability. But due to the small sample size the coefficient on the use of AD primary school programs is relatively imprecisely estimated. Moreover, the sign of the estimated coefficient is implausible, yet, not completely impossible given that Germany is rather a conservative country. ${ }^{24}$

Turning to the covariates, my estimates provide substantial evidence for positive selection into AD primary school programs. In line with my descriptive results I find that (employed) mothers with primary school-aged children in Germany exhibit a higher probability of making use of $\mathrm{AD}$ primary school programs if they are younger, have a migration background, are non-married, are better educated, and have more labor market experience (only significant in the model for the extensive margin). Moreover, they have a higher propensity to use AD primary school programs if they have fewer children or young children (only significant in the model for the intensive margin), if their family exhibits a lower monthly non-wife net household income, and if they live in urban or urbanized rather than rural areas or in former East rather than West Germany. Almost all of these maternal characteristics also positively influence maternal employment and increase the probability of full-time employment among employed mothers. There are only some exceptions: Being married negatively affects the use of AD primary school programs but positively affects maternal employment. Moreover, having more children does not significantly impact maternal employment. Finally, living in urban rather than rural areas negatively impacts maternal employment, while living in East Germany has no impact on maternal labor supply, in general.

The majority of the covariates exhibit a sign which was expected. The sign of three covariates, however, requires some additional explanation. First, being married positively affects maternal employment. Because of the so-called "Ehegattensplitting" (special tax system for spouses) and the co-insurance of dependents, in Germany married mothers have much lower work incentives than non-married mothers. But, unlike most non-married mothers, married mothers can share the care responsibilities with their spouses which eases maternal employment. Therefore, and because of the cut in unemployment benefits in 2005 married mothers often decide to work marginally. Marginal employment does not affect the tax advantages of spouses, the co-insurance of dependents and the amount of unemployment benefits. As I classified mothers who indicated marginal or irregular employment (11\% of all mother-yearobservations) as employed mothers, this explains part of the large and significantly positive

\footnotetext{
${ }^{24}$ In Germany, mothers who work and make use of institutionalized care are often considered bad mothers. Therefore, mothers who switch from care provided by friends or relatives to care provided by AD primary schools might be willing to reduce their working hours in order to spend time with their child after the AD school finishes.
} 
impact of being married on maternal employment. ${ }^{25}$

Second, for the extensive margin model my findings with regard to community size and region of residence require some additional explanation. Due to a higher availability of jobs and childcare in urban areas, I would usually expect a positive effect of community size. But I find a negative effect which is significant at the $10 \%$ level. Moreover, due to differences in work attitudes and childcare supply, I would also expect a positive impact of living in East Germany. My bivariate probit estimates, however, suggest a negative, albeit insignificant effect. To understand these counterintuitive signs it is important to see that I coded both unemployed mothers and mothers who were non-working for other reasons as non-employed. East German mothers and mothers in urban areas have a higher likelihood of being in the labor force, but if in the labor force these mothers tend to have a higher likelihood of being unemployed. For East German mothers the latter effect is likely to dominate the former effect, because only very few mothers are not in the labor force. The same holds for mothers in urban areas. $^{26}$

Table 3 presents the results which were obtained from 2SLS estimation. The structure of this table is identical to Table 2. Standard errors again allow for serial correlation across observations of the same mother. For the extensive margin, the 2SLS estimates corroborate the findings of the bivariate probit model. The first stage results again suggests that my instrument is relevant; and, the second stage estimate of the coefficient on AD primary school programs coincides with the estimate of the ATE in the bivariate probit. But being less precisely estimated, the 2SLS estimate does not reach statistical significance. Regarding the other covariates, all coefficient estimates exhibit the same sign as in the bivariate probit. For the intensive margin, the 2SLS estimates tend to differ from the bivariate probit estimates. Although the estimates for my main effect of interest are qualitatively identical - both negative and insignificant, the 2SLS estimate is 1.5 times larger than the estimated ATE in the bivariate probit. This result is, however, not very surprising given that 2SLS and the bivariate probit identify different effects in the presence of treatment effect heterogeneity. Regarding the instrument the estimates for the intensive margin are twice as large

\footnotetext{
${ }^{25} \mathrm{I}$ also estimated my bivariate probit model for the extensive margin using an alternative definition for the employment status. If I classify mothers who indicated marginal or irregular employment as non-employed mothers, the impact of the marital status decreases, but the coefficient remains significant at $5 \%$ level. My other findings were robust to this change in definition.

${ }^{26}$ Because of these findings, I also checked the robustness of my results to two alternative definitions of the employment indicator. First, I dropped mothers who were non-working for other reasons, thus, focusing on mothers who are in the labor force and I find that my results are robust to this variation. Second, I focused on labor force participation rather than employment. Again my estimate of the ATE is qualitatively the same, but smaller and thus insignificant. Surprisingly, the correlation coefficient $\rho$ is positive but insignificant in this version.
} 
Table 3. 2SLS Estimates of Maternal Labor Supply Models

\begin{tabular}{|c|c|c|c|c|}
\hline & \multicolumn{2}{|c|}{ Extensive margin } & \multicolumn{2}{|c|}{ Intensive margin $^{\mathrm{a}}$} \\
\hline & $\begin{array}{c}\text { Use of } \mathrm{AD} \\
\text { school program }\end{array}$ & Employed & $\begin{array}{c}\text { Use of } \mathrm{AD} \\
\text { school program }\end{array}$ & $\begin{array}{l}\text { Full-time } \\
\text { employed }\end{array}$ \\
\hline Use of AD school program & & $\begin{array}{c}0.293 \\
(0.346)\end{array}$ & & $\begin{array}{l}-0.589 \\
(0.386)\end{array}$ \\
\hline $\begin{array}{l}\text { Number of primary schools } \\
\text { with IZBB investments/10 }\end{array}$ & $\begin{array}{r}0.009 * * \\
(0.004)\end{array}$ & & $\begin{array}{c}0.013^{* *} \\
(0.005)\end{array}$ & \\
\hline Age (in years) & $\begin{array}{c}-0.006^{* * *} \\
(0.002)\end{array}$ & $\begin{array}{c}-0.029 * * * \\
(0.003)\end{array}$ & $\begin{array}{c}-0.007 * * * \\
(0.002)\end{array}$ & $\begin{array}{c}-0.021^{* * *} \\
(0.005)\end{array}$ \\
\hline Migration background & $\begin{array}{l}0.028^{*} \\
(0.015)\end{array}$ & $\begin{array}{c}0.006 \\
(0.023)\end{array}$ & $\begin{array}{c}0.019 \\
(0.020)\end{array}$ & $\begin{array}{c}0.128^{* * *} \\
(0.036)\end{array}$ \\
\hline Married & $\begin{array}{c}-0.084^{* * *} \\
(0.020)\end{array}$ & $\begin{array}{c}0.099 * * * \\
(0.038)\end{array}$ & $\begin{array}{c}-0.088^{* * *} \\
(0.025)\end{array}$ & $\begin{array}{c}-0.137^{* * *} \\
(0.052)\end{array}$ \\
\hline Education (in years) & $\begin{array}{c}0.011^{* * *} \\
(0.003)\end{array}$ & $\begin{array}{c}0.038^{* * *} \\
(0.006)\end{array}$ & $\begin{array}{c}0.013^{* * *} \\
(0.004)\end{array}$ & $\begin{array}{c}0.043^{* * *} \\
(0.008)\end{array}$ \\
\hline Experience (in years) & $\begin{array}{l}0.006^{*} \\
(0.003)\end{array}$ & $\begin{array}{c}0.073^{* * *} \\
(0.004)\end{array}$ & $\begin{array}{l}-0.000 \\
(0.005)\end{array}$ & $\begin{array}{c}0.011 \\
(0.007)\end{array}$ \\
\hline Experience squared & $\begin{array}{l}-0.000 \\
(0.000)\end{array}$ & $\begin{array}{c}-0.001^{* * *} \\
(0.000)\end{array}$ & $\begin{array}{c}0.000 \\
(0.000)\end{array}$ & $\begin{array}{c}0.000 \\
(0.000)\end{array}$ \\
\hline Number of children & $\begin{array}{c}-0.031^{* * *} \\
(0.008)\end{array}$ & $\begin{array}{c}0.003 \\
(0.015)\end{array}$ & $\begin{array}{c}-0.046^{* * *} \\
(0.011)\end{array}$ & $\begin{array}{c}-0.055^{* *} \\
(0.026)\end{array}$ \\
\hline Young children present & $\begin{array}{c}0.013 \\
(0.014)\end{array}$ & $\begin{array}{c}-0.189^{* * *} \\
(0.019)\end{array}$ & $\begin{array}{l}0.050^{* *} \\
(0.021)\end{array}$ & $\begin{array}{l}-0.005 \\
(0.034)\end{array}$ \\
\hline $\begin{array}{l}\text { Monthly non-wife net } \\
\text { household income/100 }\end{array}$ & $\begin{array}{c}-0.003^{* * *} \\
(0.001)\end{array}$ & $\begin{array}{c}-0.010^{* * *} \\
(0.002)\end{array}$ & $\begin{array}{c}-0.003^{* *} \\
(0.001)\end{array}$ & $\begin{array}{c}-0.013^{* * *} \\
(0.002)\end{array}$ \\
\hline Area: urbanized & $\begin{array}{c}0.036^{* * *} \\
(0.013)\end{array}$ & $\begin{array}{l}-0.021 \\
(0.024)\end{array}$ & $\begin{array}{c}0.027 \\
(0.017)\end{array}$ & $\begin{array}{c}0.030 \\
(0.031)\end{array}$ \\
\hline Area: urban & $\begin{array}{c}0.111^{* * *} \\
(0.017)\end{array}$ & $\begin{array}{l}-0.036 \\
(0.046)\end{array}$ & $\begin{array}{c}0.123^{* * *} \\
(0.023)\end{array}$ & $\begin{array}{c}0.148^{* *} \\
(0.063)\end{array}$ \\
\hline East Germany & $\begin{array}{c}0.417^{* * *} \\
(0.087)\end{array}$ & $\begin{array}{l}-0.098 \\
(0.163)\end{array}$ & $\begin{array}{c}0.440^{* * *} \\
(0.108)\end{array}$ & $\begin{array}{c}0.205 \\
(0.248)\end{array}$ \\
\hline State FE & Yes & & Yes & \\
\hline Year FE & Yes & & Yes & \\
\hline Observations & 5010 & & 3047 & \\
\hline
\end{tabular}

Notes: The variable use of AD primary school program is instrumented with the number of primary schools per county receiving IZBB investments in a given year. Models additionally include a constant. Standard errors that allow for serial correlation across observations of the same mother are reported in parentheses.

a 2SLS estimates for the intensive margin are conditional on maternal employment.

$* \mathrm{p}<0.1$ ** $\mathrm{p}<0.05^{* * *} \mathrm{p}<0.01$.

Sources: SOEPv30 (2003-2009) \& SPI NRW (2010), own estimates. 
under 2SLS, but continue to exhibit the same level of significance. The other covariates are qualitatively identical, except of the indicator for East Germany which changes it sign, but remains statistically insignificant.

As an additional robustness check, I also computed a lower bound estimate of the ATE for the extensive margin model. Due to the negative correlation between the two structural errors in the extensive margin model, a single-equation probit for maternal employment provides, after controlling for differences in observable maternal characteristics, a lower bound estimate for the ATE. The probit estimates show that this lower bound estimate of the ATE is roughly five times smaller than my bivariate probit estimate of the ATE. Yet, the lower bound ATE estimate remains statistically significant at the $5 \%$ level. Thus, this finding further supports the argument that AD primary school programs have a positive impact on maternal labor supply at the extensive margin. ${ }^{27}$

\subsection{Treatment Effect Heterogeneity}

This section provides some evidence on treatment effect heterogeneity for the extensive margin model. Due to the small sample size, however, I do not proceed as usual. Initially, I focus on mothers who live in states with AD primary school student shares of up to $10 \%$. Then, I gradually augment this sample of mothers with mothers who live in states with higher and higher AD primary school students shares. For each of these samples I estimate the maternal labor supply model for the extensive margin using a bivariate probit model and 2SLS. The results of this analysis are presented in Table 4.

My estimates suggest that the large effect of AD primary school programs on maternal employment is mainly concentrated in states with AD primary school student shares of up to $20 \%$. According to my bivariate probit estimates the ATE is strongest for mothers who live in states with AD primary school student shares of up to $15 \%$ or $20 \%$. On average, mothers who live in these states have a 29 ppts higher likelihood of engaging in employment if they make use of the AD primary school program. Upon the addition of mothers who live in states with AD primary school student shares of 15 to $20 \%$, the ATE declines by roughly one third. Then, if I further add mothers who live in states with higher and higher AD primary school student shares the ATE remains of a comparable magnitude. These findings are corroborated by the 2SLS estimates which exhibit a similar pattern across samples. Yet, 2SLS estimates are not always as close to the bivariate probit estimates. In particular, for very small sample sizes 2SLS estimates suggest a much larger effect than the bivariate

\footnotetext{
${ }^{27}$ The lower bound estimate of the ATE based on the probit coincides with the one obtained from the linear probability model.
} 
Table 4. Treatment Effect Heterogeneity by Share of AD Primary School Students - Extensive Margin Model

\begin{tabular}{ccccccccc}
\hline & & \multicolumn{3}{c}{ Bivariate probit estimates } & & \multicolumn{2}{c}{ 2SLS estimates } & \\
\cline { 3 - 4 } Sample & Share & coefficient & ATE & $\rho$ & & AD & First stage & \\
$(1)$ & $\leq 10 \%$ & $1.182^{* * *}$ & $0.262^{* * *}$ & $-0.497^{* *}$ & & $0.631^{*}$ & 10.304 & 3458 \\
& & $(0.427)$ & $(0.076)$ & $(0.220)$ & & $(0.329)$ & {$[0.001]$} & \\
$(2)$ & $\leq 15 \%$ & $1.330^{* * *}$ & $0.288^{* * *}$ & $-0.597^{* * *}$ & & $0.381^{*}$ & 14.751 & 3892 \\
& & $(0.281)$ & $(0.047)$ & $(0.142)$ & & $(0.231)$ & {$[0.000]$} & \\
$(3)$ & $\leq 20 \%$ & $1.329^{* * *}$ & $0.287^{* * *}$ & $-0.597^{* * *}$ & & 0.373 & 14.904 & 3939 \\
& & $(0.277)$ & $(0.047)$ & $(0.140)$ & & $(0.230)$ & {$[0.000]$} & \\
$(4)$ & $\leq 25 \%$ & $0.842^{* *}$ & $0.198^{* *}$ & $-0.372^{*}$ & & 0.181 & 20.900 & 4330 \\
& & $(0.390)$ & $(0.082)$ & $(0.210)$ & & $(0.212)$ & {$[0.000]$} & \\
$(5)$ & $\leq 30 \%$ & $0.847^{* *}$ & $0.199^{* *}$ & $-0.377^{*}$ & & 0.166 & 12.886 & 4370 \\
& & $(0.417)$ & $(0.087)$ & $(0.224)$ & $(0.228)$ & {$[0.000]$} & \\
\hline
\end{tabular}

Notes: The dependent variable is a 0-1 dummy variable for maternal employment. It takes the value 1 if a mother is employed and 0 else. The variable use of AD primary school program is instrumented with the number of primary schools per county receiving IZBB investments in a given year. The share of AD primary school students on all primary school students is measured at the state level on a yearly basis. Covariates correspond to those of Tables 2 and 3. Standard errors that allow for serial correlation across observations of the same mother are reported in parentheses. P-values are reported in squared brackets.

$* \mathrm{p}<0.1$ ** $\mathrm{p}<0.05 * * * \mathrm{p}<0.01$.

Sources: SOEPv30 (2003-2009), KMK (2014) \& SPI NRW (2010), own estimates.

probit estimates do. ${ }^{28}$ As 2SLS identifies the local average treatment effect (LATE) and the bivariate probit the ATE, this further supports supports the argument that mothers who live in states with low AD primary school student shares respond stronger to the provision of AD primary school programs.

Regarding instrument relevance, my estimates suggest that my instrument tends to be stronger if I focus on mothers who live in states with lower AD primary school student shares. For example, if IZBB investments were allocated to 10 additional primary schools in the county of residence the probability of mothers to make use of AD primary school programs would increase by 1.7 ppts among those mothers who live in states with AD primary school student shares of up to $15 \%$. This effect is more than three times larger than the effect of the instrument for the full sample of mothers. It declines by more than the half, if I focus on mothers who live in states with AD primary school student shares of up to $30 \%$. This finding is consistent with the 2SLS estimates which suggest a lower value of the first stage F-statistic if I focus on the full sample of mothers rather than the restricted samples

\footnotetext{
${ }^{28}$ In a simulation study Chiburis et al. (2012) show that both estimates tend to substantially differ if sample sizes are below 5,000 or if treatment probabilities are close to 0 or 1 , both of which is the case in my situation.
} 
of mothers.

\subsection{Further Robustness Checks}

This section provides a battery of robustness checks for the extensive margin model. More specifically, I test the sensitivity of my results to the use of alternative and lagged instruments, to variations in the definition of the $\mathrm{AD}$ indicator, and to the inclusion of additional sets of controls. I find that my results for the extensive margin are very robust.

Table A.2 in the appendix presents bivariate probit and 2SLS estimates for models which use alternative instruments. I find that my bivariate probit and 2SLS estimates change only very little. One exception is the 2SLS estimate which is reported in row 5. Upon the inclusion of three instruments - the number of primary schools with IZBB investments, the share of AD primary schools and the interaction between the two - the 2SLS estimate drops by more than four fifth. Yet, it continues to exceed my lower bound estimate. As my bivariate probit estimates, however, remain basically unchanged in this alternative specification, I do not consider this drop of the 2SLS estimate a limitation of my results.

I perform two additional tests to enhance the understanding about the validity of my instruments. First, given that some of my models in Table A.2 are overidentified, I test based on Sargan-Hansen's J-test of overidentifying restrictions whether my set of instruments can be rejected. As indicated in column 7 of Table A.2, the $\mathrm{H} 0$ of no overidentification can not be rejected. Second, I estimate single-equation probit models of the maternal employment status on my set of controls and the instrument(s). After controlling for observed maternal characteristics, there should be no direct impact of the instrument(s) on maternal employment. I find that upon the inclusion of my different sets of instruments in the single-equation probit model the coefficient estimates do not change. Moreover, the instruments turn out to be insignificant in all my regressions. ${ }^{29}$

As schools that received IZBB investments were not necessarily able to provide an AD school program immediately, I reestimate my bivariate probit model using instruments which are lagged by one period. The respective results are presented in Table A.3 in the appendix. My estimates indicate that the effect of my instrument on the probability of mothers to make use of AD primary school programs decreases rather than increases under this specification. Due to the smaller number of observations - I loose observations of the year 2003 - estimates are less precisely estimated and only reach statistical significance at the $10 \%$ level. Therefore,

\footnotetext{
${ }^{29}$ I recognize that both test are only informal tests. The J-test assumes that at least one instrument is valid. If all instruments are invalid, non-rejection of the H0 does not proof the validity of my instruments. The inclusion test is based on the single-equation probit which is likely to be biased in the presence of selection on unobservables.
} 
I conclude that the lagged instruments are weaker. The potential weakness of the lagged instruments is also reflected in lower coefficient estimates of the AD school indicator in the employment equation and, accordingly, lower estimates of the ATE.

Table A.4 in the appendix shows the results for my bivariate probit estimates using alternative definitions of the indicator for the use of AD primary school programs. Although $15 \%$ of the observations in my sample refer to mothers who have more than one primary school-aged child, changes in the definition of the AD school indicator do not affect my estimation results. My bivariate probit estimates and the estimate of the ATE, in particular, remain of similar magnitude. The first and the second definition are very similar. This suggests that mothers who have more than one primary school-aged child, in general, come to the same decision for all of their primary school-aged children. There are very few mothers who decide to use the AD school program only for some of their primary school-aged children, bot not for others. Indeed, in my sample less than $2 \%$ of the observations which refer to mothers with more than one primary school-aged child refer to mothers who decided differently upon the attendance of AD school programs across their primary school-aged children.

Finally, in Table A.5 in the appendix I test the sensitivity to the inclusion of additional sets of controls. The use of alternative types of care is likely to affect both maternal decisions: First, mothers who have access to family care, for example, may be more reluctant to make use of AD primary school programs. Second, mothers who use alternative types of care have more time that can be spent on the labor market. Therefore, I should control for the maternal use of alternative types of care. This, however, comes at some costs. As information on the use of paid and unpaid care was not gathered in 2003 I would loose $16 \%$ of my observations. Moreover, due to item-non-response in the care variables, I would loose additional $3 \%$ of my observations, if I decided not to control for missing information in the care variables. Most importantly, however, I would be likely to induce a bias, if I were not to instrument for the use of alternative types of care. As there is no instrument in my data set which could be used to instrument for the use of alternative types of care, I decided to add care variables to my main specification as a robustness check. Both the indicator for the use of alternative types of care and the indicator for missing care information show up significant in the use of $\mathrm{AD}$ school program equation and the employment equation. But the ATE only changes very little independent of whether I keep observations of the year 2003 (included in the missing dummy, column 1) or exclude them (column 2).

Work preferences are one of my main concerns for positive selection into AD primary school programs. While work preferences are not directly measured in the SOEP, there is a variable - the importance of job success - which can serve as a proxy for work preferences. 
But information on the importance of job success was only gathered in 1995, 2004, 2008 and 2012. Thus, to fill in the gaps I assume that preferences are relatively stable and carry forward the information on the importance of job success. I also carry backward this information for survey respondents who entered the sample due to refreshment. The rough measure of work preferences that I obtain continues to contain some missing values due to itemnonresponse, wherefore I include a dummy variable for missing values in my bivariate probit regression. I distinguish between missing, low, medium, and high work preferences and high work preferences serves as reference category in my regression. I find that preferences have no significant impact on the maternal use of AD primary school programs, but do significantly impact maternal employment (column 3). When compared to mothers with high work preferences, mothers with low work preferences are less likely to engage in employment. As work preferences turn out to be insignificant in the AD school equation, it is not surprising that my estimate of $\rho$ remains unaffected by the inclusion of work preferences. The ATE also remains of similar magnitude.

Previous literature has shown that the unemployment rate can be a determinant of the employment decision (Killingsworth \& Heckman 1986). Therefore, I also tested the robustness of my results to the inclusion of the female regional unemployment rate. My bivariate probit estimates indicate that the female regional unemployment rate is insignificant. Consequently, the estimate of the ATE does not change (column 4).

\section{Conclusion}

Primary school-aged children still require a significant amount of maternal care. Thus, as do preschool-aged children, primary school-aged children impede maternal labor supply. For this reason, I have analyzed the effect of AD primary school programs on maternal labor supply at both the extensive and the intensive margin. To address AD school selectivity and selection into AD primary school programs I estimated bivariate probit models. To identify these models I exploited temporal and county level variation in the allocation of IZBB investments to AD primary schools, which resulted from the IZBB program in Germany.

Based on SOEP data and two administrative data sets on AD schools I have found that AD primary school programs significantly impact maternal labor supply at the extensive margin. On average, mothers who make use of AD primary school programs are 26 ppts more likely to be employed than mothers who do not make use of these programs. This large effect is mainly driven by mothers who live in states with AD primary school student shares of up to $20 \%$, hence, supporting a decreasing returns to scale story. I have shown that my findings on the extensive margin are very robust to alternative specifications and estimation strategies. In particular, my bivariate probit estimates are of similar magnitude as my 2SLS 
estimates. Being more precisely estimated, however, they reach statistical significance while the 2SLS estimates do not. I also computed a lower bound estimate for the ATE, which albeit five times smaller than my estimate of the ATE in the main specification remains significant at the $5 \%$ level.

Somewhat surprising, selection into AD primary school programs turned out to be negative in the extensive margin model. I have provided two possible explanations for this negative selection into AD primary school programs. First, the low acceptance of AD primary school programs among mothers with stronger work preferences. Second, the broad variety of different classes and extracurricular activities offered by AD primary schools which renders AD primary school programs particularly attractive for mothers with lower work preferences who often due to a lower family income are less able to promote their child's interest. Both interpretations are consistent with Börner et al. (2010).

I have found no evidence for an impact of AD primary school programs on maternal labor supply at the intensive margin. There are several explanations for this finding. For example, the operating hours of $\mathrm{AD}$ programs may be to restrictive for mothers to engage in full-time employment. Or, because of conservative work attitudes (in particular in West Germany) mothers may decide to work part-time rather than full-time. If part-time employed mothers only marginally increased their hours of work in response to AD primary school programs, I would not be able to uncover an effect on maternal labor supply at the intensive margin by distinguishing between part-time and full-time employment. To address this issue future research can either analyze different cut-off values for full-time employment (e.g. full-time employment equal to 20 hours and more) within the bivariate probit framework or directly focus on the number of working hours. 


\section{References}

Augustin-Dittmann, S. (2010). The Development of All-Day Schooling in Germany: How was it possible in this Conservative Welfare State? German Policy Studies, 6, 49-81.

Baker, M., Gruber, J., \& Milligan, K. (2008). Universal Child Care, Maternal Labor Supply, and Family Well-Being. Journal of Political Economy, 116, 709-745.

Bauernschuster, S., \& Schlotter, M. (2015). Public child care and mothers' labor supply Evidence from two quasi-experiments. Journal of Public Economics, 123, 1-16.

Beblo, M., Lauer, C., \& Wrohlich, K. (2005). Ganztagsschulen und Erwerbsbeteiligung von Müttern - eine Mikrosimulationsstudie für Deutschland (All-day schools and labour force participation of mothers - a micro-simulation study for Germany). Zeitschrift für Arbeitsmarktforschung - Journal for Labour Market Research, 38, 357-372.

Becker, G. S. (1991). A Treatise on the Family. Cambridge, MA: Harvard University Press.

Berlinski, S., \& Galiani, S. (2007). The effect of a large expansion of pre-primary school facilities on preschool attendance and maternal employment. Labour Economics, 14, 665680.

Bertelsmann Stiftung (2012). Ganztagsschule als Hoffnungsträger für die Zukunft? Ein Reformprojekt auf dem Prüfstand. Expertise des Deutschen Jugendinstituts (DJI) im Auftrag der Bertelsmann Stiftung. Gütersloh: Verlag Bertelsmann Stiftung.

Berthelon, M. E., Kruger, D. I., \& Oyarzùn, M. (2015). The effects of longer school days on mothers' labor force participation. IZA Discussion Paper, No. 9212.

Bildungsbericht (Autorengruppe Bildungsberichterstattung) (2012). Bildung in Deutschland 2012. Ein indikatorengestützter Bericht mit einer Analyse zur kulturellen Bildung im Lebenslauf. Bielefeld: W. Bertelsmann Verlag. www.bildungsbericht.de/daten2012/ bb_2012.pdf, accessed on 10 September 2015.

Blau, D. M., \& Hagy, A. P. (1998). The Demand for Quality in Child Care. Journal of Political Economy, 106, 104-146.

Blau, D. M., \& Robins, P. K. (1988). Child-Care Costs and Family Labor Supply. The Review of Economics and Statistics, 70, 374-81. 
Blossfeld, H.-P., Bos, W., Daniel, H.-D., Hannover, B., Lenzen, D., Prenzel, M., Roßbach, H.G., Tippelt, R., \& Wößmann, L. (2013). Zwischenbilanz Ganztagsgrundschulen: Betreuung oder Rhythmisierung? Gutachten. Münster: Waxmann.

Bonin, H., \& Euwals, R. (2005). Why Are Labor Force Participation Rates of East German Women So High? Applied Economics Quarterly, 51, 359-386.

Börner, N., Beher, K., Düx, W., \& Züchner, I. (2010). Lernen und Fördern aus Sicht der Eltern. In Lernen und Fördern in der offenen Ganztagsschule. Vertiefungsstudie zum Primarbereich in Nordrhein-Westfalen Juventa: Materialien (pp. 143-225). Weinheim u.a.: Juventa.

Bundesministerium für Bildung und Forschung (Ed.) (BMBF) (2003). Verwaltungsvereinbarung zwischen der Bundesrepublik Deutschland und den Bundesländern zum Investitionsprogramm "Zukunft Bildung und Betreuung" 2003 - 2007. www.ganztagsschulen.org/_media/20030512_verwaltungsvereinbarung_ zukunft_bildung_und_betreuung.pdf, accessed on 12 September 2015.

Bundesministerium für Bildung und Forschung (Ed.) (BMBF) (2009). Gut angelegt Das Investitionsprogramm Zukunft Bildung und Betreuung. www.ganztagsschulen.org/ _media/gut_angelegt.pdf, accessed on 12 September 2015.

Bundesministerium für Familie, Senioren, Frauen und Jugend (BMFSFJ) (1996). Zeit im Blickfeld - Ergebnisse einer repräsentativen Zeitbudgeterhebung (Schriftenreihe Bd. 121). Stuttgart, Berlin, Köln: Kohlhammer.

Bundesministerium für Familie, Senioren, Frauen und Jugend (BMFSFJ) (2011). Vereinbarkeit von Familie und Beruf mit Schulkindern. www . bmf sf j . de/RedaktionBMFSFJ/Broschuerenstelle/Pdf-Anlagen/_C3_ 9C-6-Vereinbarkeit-von-Familie-und-Beruf-mit-Schulkindern, property=pdf , bereich=bmf sf $j$, sprache=de, rwb=true.pdf, accessed on 11 September 2015.

Bundesministerium für Familie, Senioren, Frauen und Jugend (BMFSFJ) (2013). 13. Kinder- und Jugendbericht. Bericht über die Lebenssituation junger Menschen und die Leistungen der Kinder- und Jugendhilfe in Deutschland. Berlin: Bundestagsdrucksache 17/12200. www.bmfsfj.de/RedaktionBMFSFJ/Broschuerenstelle/Pdf-Anlagen/ 13-kinder-jugendbericht, property=pdf, bereich=bmfsf j, rwb=true.pdf, accessed on 11 September 2015. 
Bundesvereinigung Kulturelle Kinder- und Jugendbildung e.V. (BKJ) (2006). Kulturelle Bildung und Ganztagsschulen: Rahmenbedingungen und Umsetzung von Kooperationen in den Ländern. Eine Ländersynopse. www.miz.org/dokumente/bkj_Laendersynopse. pdf, accessed on 12 September 2015.

Cascio, E. U. (2009). Maternal Labor Supply and the Introduction of Kindergartens into American Public Schools. Journal of Human Resources, 44, 140-170.

Cascio, E. U., Haider, S. J., \& Skyt Nielsen, H. (2015). The effectiveness of policies that promote labor force participation of women with children: A collection of national studies. Labour Economics, 36, 64-71.

Chiburis, R. C., Das, J., \& Lokshin, M. (2012). A practical comparison of the bivariate probit and linear IV estimators. Economics Letters, 117, 762-766.

Contreras, D., Sepúlveda, P., \& Cabrera, S. (2010). The effects of lengthening the school day on female labor supply: Evidence from a quasi-experiment in Chile. Serie Documentos de Trabajo, No. 323. University of Chile, Department of Economics.

Dehos, F., \& Paul, M. (2015). The Effects of After-School Programs on Maternal Employment. Working Paper, September 2015. Ruhr-Graduate School in Economics and University of Duisburg-Essen.

Deutsches Jugendinstitut (Ed.) (DJI) (2005). Zahlenspiegel 2005. Kindertagesbetreuung im Spiegel der Statistik. www.bmfsfj.de/doku/Publikationen/ zahlenspiegel2005/01-Redaktion/PDF-Anlagen/Gesamtdokument, property=pdf , bereich=zahlenspiegel2005, sprache=de, rwb=true.pdf, accessed on 9 September 2015 .

Dohmen, D., \& Himpele, K. (2006). Kosten von Ganztagsschulen. Recht der Jugend und des Bildungswesens, issue 1/2006.

Felfe, C., Lechner, M., \& Thiemann, P. (2015). After-School Care and Parents' Labor Supply. USC-INET Research Paper, No. 15-21.

Fitzpatrick, M. (2010). Preschoolers Enrolled and Mothers at Work? The Effects of Universal Prekindergarten. Journal of Labor Economics, 28, 51-85.

Gelbach, J. B. (2002). Public Schooling for Young Children and Maternal Labor Supply. American Economic Review, 92, 307-322. 
Hagemann, K. (2009). Die Ganztagsschule als Politikum. Die bundesdeutsche Entwicklung in gesellschafts- und geschlechtergeschichtlicher Perspektive. In L. Stecher, C. AllemannGhionda, W. Helsper, \& E. Klieme (Eds.), Ganztägige Bildung und Betreuung (pp. 209229). Weinheim: Beltz.

Havnes, T., \& Mogstad, M. (2011). Money for nothing? Universal child care and maternal employment. Journal of Public Economics, 95, 1455-1465.

Killingsworth, M. R., \& Heckman, J. J. (1986). Female labor supply: A survey. In O. C. Ashenfelter, \& R. Layard (Eds.), Handbook of Labor Economics, Vol. 1 (pp. 103-204). Elsevier.

Konferenz der Kultusminister der Bundesrepublik Deutschland (Ed.) (KMK) (2014). Allgemein bildende Schulen in Ganztagsform in den Ländern in der Bundesrepublik Deutschland, verschiedene Jahre (2008-2014). www.kmk.org/statistik/schule/statistische-veroeffentlichungen/ allgemeinbildende-schulen-in-ganztagsform.html, accessed on 23 May 2015.

Kreyenfeld, M., \& Geisler, E. (2006). Müttererwerbstätigkeit in Ost- und Westdeutschland. Zeitschrift für Familienforschung - Journal of Family Research, 18, 333-360.

Lundin, D., Mörk, E., \& Öckert, B. (2008). How far can reduced childcare prices push female labour supply? Labour Economics, 15, 647-659.

Marcus, J., Nemitz, J., \& Spieß, K. C. (2013). Ausbau der Ganztagsschule: Kinder aus einkommensschwachen Haushalten im Westen nutzen Angebote verstärkt. DIWWochenbericht 2013, 27, 11-23.

Marcus, J., Nemitz, J., \& Spieß, K. C. (2015). Zeitschrift für Erziehungswissenschaft German Journal of Educational Science, (pp. 1-28).

Ribar, D. C. (1992). Child Care and the Labor Supply of Married Women: Reduced Form Evidence. Journal of Human Resources, 27, 134-165. doi:http://doi.org/10.2307/ 145915.

Rosenfeld, R. A., Trappe, H., \& Gornick, J. C. (2004). Gender and Work in Germany: Before and After Reunification. Annual Review of Sociology, 30, 103-124.

Sozialpädagogisches Institut NRW, TH Köln (SPI NRW) (2010). Investitionsprogramm "Zukunft Bildung und Betreuung" 2003-2009. Geförderte Schulen in den Jahren 2003, 2004, 2005, 2006, 2007, 2008, 2009, verschiedene Bundesländer. Wiesbaden. 
Statistisches Bundesamt (2012). Vereinbarkeit von Familie und Beruf. Ergebnisse des Mikrozensus 2011. Wiesbaden. www.destatis.de/DE/Publikationen/ WirtschaftStatistik/Bevoelkerung/VereinbarkeitFamilieBeruf_122012.pdf?-blob=publicationFile, accessed on 10 September 2015.

Statistisches Bundesamt (2013). Allgemeinbildende Schulen. Fachserie 11 Reihe 1 Schuljahr 2012/13. Wiesbaden. www.destatis.de/DE/Publikationen/Thematisch/ BildungForschungKultur/Schulen/AllgemeinbildendeSchulen2110100137004 .pdf? _-_blob=publicationFile, accessed on 8 June 2015.

Wagner, G. G., Frick, J. R., \& Schupp, J. (2007). The German Socio-Economic Panel Study (SOEP) - Scope, Evolution and Enhancements. Schmollers Jahrbuch, 127, 139-169.

Wooldridge, J. M. (2010). Econometric Analysis of Cross Section and Panel Data. Cambridge, MA: The MIT Press. 


\section{Appendix A.}

Table A.1. Definition of Variables

\begin{tabular}{|c|c|}
\hline Variable name & Definition \\
\hline \multicolumn{2}{|l|}{ Main variables } \\
\hline Use of $\mathrm{AD}$ school program $(A D)$ & $\begin{array}{l}0-1 \text { dummy variable, }=1 \text { if mother makes use of the } \\
\text { AD primary school program for at least one primary } \\
\text { school-aged child in the household (main specification) }\end{array}$ \\
\hline Employed $(E)$ & $0-1$ dummy variable, $=1$ if employed \\
\hline Full-time employed $(F T E)$ & $0-1$ dummy variable, $=1$ if full-time employed \\
\hline \multicolumn{2}{|l|}{ Instruments } \\
\hline IZBB investments & $\begin{array}{l}0-1 \text { dummy variable, }=1 \text { if mother lives in a county } \\
\text { whose primary schools received IZBB investments } \\
\text { (county level, yearly basis) }\end{array}$ \\
\hline $\begin{array}{l}\text { Number of primary schools with } \\
\text { IZBB investments } / 10\end{array}$ & $\begin{array}{l}\text { Number of primary schools that received IZBB } \\
\text { investments, measured in units of } 10 \text { schools (county } \\
\text { level, yearly basis) }\end{array}$ \\
\hline $\begin{array}{l}\text { Amount of IZBB invest- } \\
\text { ments } / 10 \text { million }\end{array}$ & $\begin{array}{l}\text { Amount of IZBB investments allocated to primary } \\
\text { schools in } € 10 \text { million (county level, yearly basis) }\end{array}$ \\
\hline Share of AD primary schools & $\begin{array}{l}\text { Share of AD primary schools among all primary } \\
\text { schools (state level, yearly basis) }\end{array}$ \\
\hline $\begin{array}{l}\text { Share of AD primary school } \\
\text { students }\end{array}$ & $\begin{array}{l}\text { Share of AD primary school students among all } \\
\text { primary school students (state level, yearly basis) }\end{array}$ \\
\hline \multicolumn{2}{|l|}{ Maternal characteristics } \\
\hline Age & Age at the time of the interview (in years) \\
\hline Migration background & $0-1$ dummy variable, $=1$ if migration background \\
\hline Married & $0-1$ dummy variable, $=1$ if married \\
\hline Education & Number of years spent in education \\
\hline Experience & Number of years of labor market experience \\
\hline Work preferences & $\begin{array}{l}\text { Importance of job success on a } 1 \text { to } 4 \text { point scale, } 4 \\
\text { categories: missing, low ( } 4 \text { or } 3 \text { ), medium (2), high (1) }\end{array}$ \\
\hline \multicolumn{2}{|l|}{ Family characteristics } \\
\hline Number of children & $\begin{array}{l}\text { Number of children who live in household and are aged } \\
\text { less than } 18\end{array}$ \\
\hline Young children present & $\begin{array}{l}0-1 \text { dummy variable, }=1 \text { if } 0 \text { to } 5 \text { year-old children live } \\
\text { in the household }\end{array}$ \\
\hline Use of other care & $\begin{array}{l}2 \text { categories: missing, use of other care (mother makes } \\
\text { use of alternative types of care for at least one primary } \\
\text { school-aged child in the household) }\end{array}$ \\
\hline $\begin{array}{l}\text { Monthly non-wife net household } \\
\text { income/100 }\end{array}$ & $\begin{array}{l}\text { Need-weighted deflated monthly net household income } \\
\text { net of the mother's labor earnings in } € 100\end{array}$ \\
\hline Size of community (area) & $\begin{array}{l}3 \text { categories: rural (<20,000 inhabitants), urbanized } \\
\text { ( } 20,000 \text { to } 100,000 \text { inhabitants), urban }(>100,000 \\
\text { inhabitants) }\end{array}$ \\
\hline East Germany & $\begin{array}{l}0-1 \text { dummy variable, }=1 \text { if mother lives in former East } \\
\text { Germany }\end{array}$ \\
\hline Female unemployment rate & Female unemployment rate (county level, yearly basis) \\
\hline
\end{tabular}




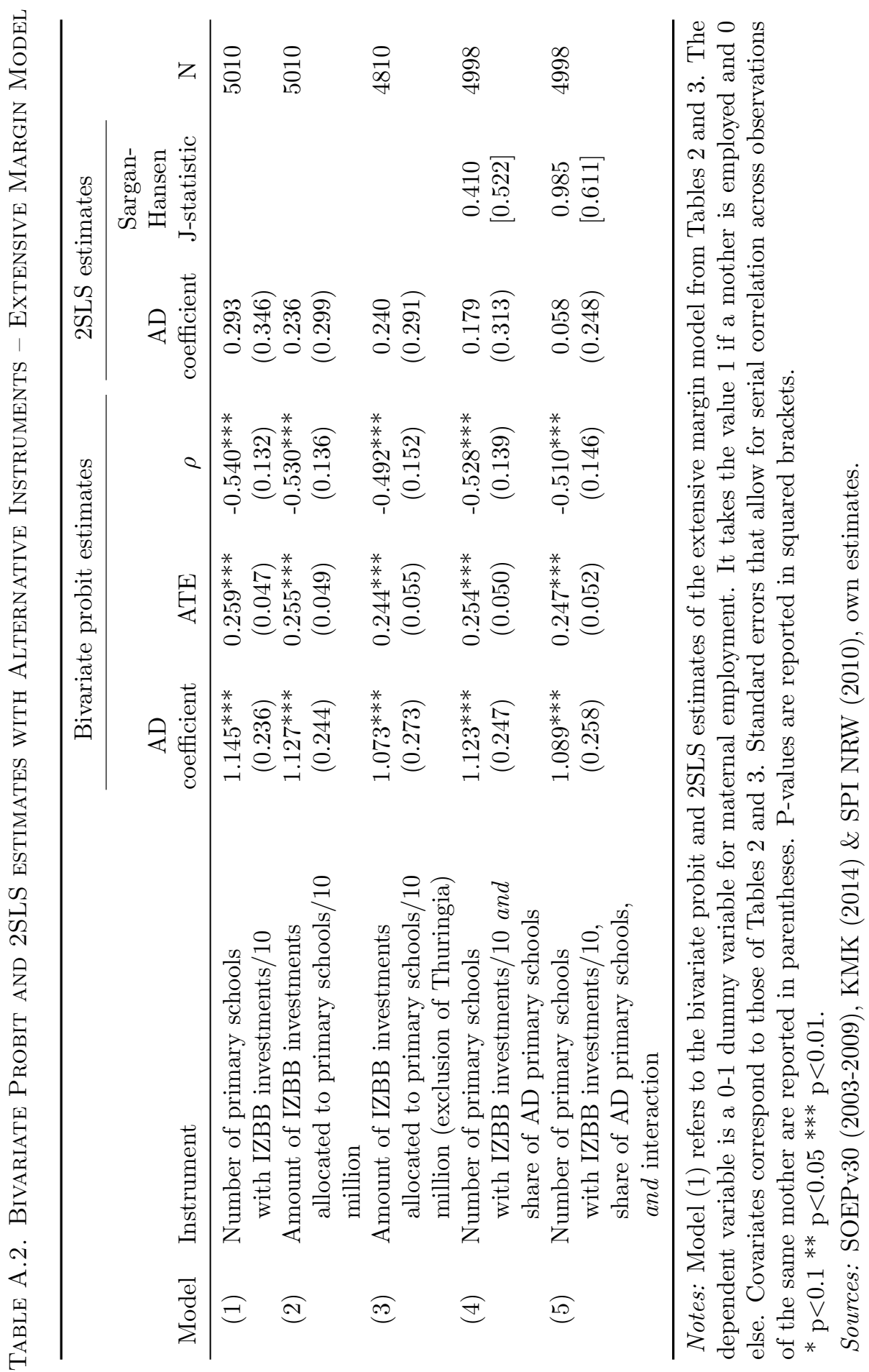


Table A.3. Bivariate Probit Estimates Using Lagged Instruments - Extensive Margin Model

\begin{tabular}{lcc}
\hline & \multicolumn{2}{c}{ Lagged instrument } \\
\cline { 2 - 3 } & $\begin{array}{c}(1) \\
\text { Number of primary } \\
\text { schools with IZBB } \\
\text { investments }\end{array}$ & $\begin{array}{c}\text { Amount of IZBB } \\
\text { investments allocated } \\
\text { to primary schools }\end{array}$ \\
\hline Estimates of & $0.921^{* *}$ & $0.870^{*}$ \\
AD coefficient in & $(0.405)$ & $(0.453)$ \\
employment equation & $0.024^{*}$ & $0.170^{*}$ \\
Coefficient on lagged & $(0.013)$ & $(0.087)$ \\
instrument in AD equation & $-0.412^{*}$ & -0.382 \\
$\rho$ & $(0.230)$ & $(0.258)$ \\
& $0.207^{* *}$ & $0.196^{* *}$ \\
ATE & $(0.083)$ & $(0.094)$ \\
Observations & 4196 & 4196 \\
\hline
\end{tabular}

Notes: Covariates correspond to those of Tables 2 and 3. Standard errors that allow for serial correlation across observations of the same mother are reported in parentheses.

$* \mathrm{p}<0.1 * * \mathrm{p}<0.05 * * * \mathrm{p}<0.01$.

Sources: SOEPv30 (2003-2009) \& SPI NRW (2010), own estimates. 
Table A.4. Bivariate Probit Estimates Using Alternative Definitions of the AD IndicAtor - Extensive Margin Model

\begin{tabular}{|c|c|c|c|}
\hline \multirow[b]{2}{*}{ Estimates of } & \multicolumn{3}{|c|}{ Definition of AD indicator } \\
\hline & $\begin{array}{c}\text { (1) } \\
=1 \text { if at least one } \\
\text { primary school-aged } \\
\text { child in the household } \\
\text { makes use of the } \\
\text { AD school program }\end{array}$ & $\begin{array}{l}(2) \\
=1 \text { if all primary } \\
\text { school-aged children } \\
\text { in the household } \\
\text { make use of the } \\
\text { AD school program }\end{array}$ & $\begin{array}{l}=1 \text { if the only prim. } \\
\text { school-aged child } \\
\text { in the household } \\
\text { makes use of the } \\
\text { AD school program }\end{array}$ \\
\hline $\begin{array}{l}\text { AD coefficient in } \\
\text { employment equation }\end{array}$ & $\begin{array}{c}1.145^{* * *} \\
(0.236)\end{array}$ & $\begin{array}{c}1.089^{* * *} \\
(0.257)\end{array}$ & $0.949^{* * *}$ \\
\hline $\begin{array}{l}\text { Coefficient on instrument } \\
\text { in } \mathrm{AD} \text { equation }\end{array}$ & $\begin{array}{c}0.032^{* *} \\
(0.013)\end{array}$ & $\begin{array}{c}0.027^{* *} \\
(0.013)\end{array}$ & $\begin{array}{l}0.029^{* *} \\
(0.014)\end{array}$ \\
\hline$\rho$ & $\begin{array}{c}-0.540^{* * *} \\
(0.132)\end{array}$ & $\begin{array}{c}-0.499^{* * *} \\
(0.145)\end{array}$ & $\begin{array}{c}-0.429^{* *} \\
(0.205)\end{array}$ \\
\hline ATE & $\begin{array}{c}0.259^{* * *} \\
(0.047)\end{array}$ & $\begin{array}{c}0.247^{* * *} \\
(0.052)\end{array}$ & $\begin{array}{c}0.219^{* * *} \\
(0.075)\end{array}$ \\
\hline Observations & 5010 & 5010 & 4244 \\
\hline
\end{tabular}

Notes: The number of primary schools per county receiving IZBB investments in a given year is used as instrument. Covariates correspond to those of Tables 2 and 3. Standard errors that allow for serial correlation across observations of the same mother are reported in parentheses.

a Model (1) corresponds to the extensive margin model in Table 2.

b Model (3) is based on a somewhat smaller sample of mothers, as I exclude maternal observations if more than one primary school-aged child lives in the household.

$* \mathrm{p}<0.1 * * \mathrm{p}<0.05 * * * \mathrm{p}<0.01$.

Sources: SOEPv30 (2003-2009) \& SPI NRW (2010), own estimates. 
Table A.5. Bivariate Probit Estimates with Additional Controls Extensive Margin Model

\begin{tabular}{lcccc}
\hline & \multicolumn{3}{c}{ Additional sets of controls } \\
\cline { 2 - 5 } & $(1)$ & $(2)$ & $(3)$ & $(4)$ \\
& Use of & Use of & & Female \\
Estimates of & alternative & alternative & Working & $\begin{array}{c}\text { unemployment } \\
\text { rate }\end{array}$ \\
\hline AD coefficient in & $1.116^{* * *}$ & $0.953^{* * *}$ & $1.087^{* * *}$ & $1.155^{* * *}$ \\
employment equation & $(0.239)$ & $(0.357)$ & $(0.261)$ & $(0.237)$ \\
AD school equation & & & & \\
Coefficient on instrument & $0.030^{* *}$ & $0.039^{* * *}$ & $0.032^{* *}$ & $0.032^{* *}$ \\
in AD equation & $(0.013)$ & $(0.014)$ & $(0.013)$ & $(0.013)$ \\
$\rho$ & $-0.553^{* * *}$ & $-0.467^{* *}$ & $-0.512^{* * *}$ & $-0.545^{* * *}$ \\
& $(0.133)$ & $(0.202)$ & $(0.145)$ & $(0.132)$ \\
ATE & & & & $0.261^{* * *}$ \\
Observations & $0.250^{* * *}$ & $0.210^{* * *}$ & $0.245^{* * *}$ & $(0.048)$ \\
\hline
\end{tabular}

Notes: The number of primary schools per county receiving IZBB investments in a given year is used as instrument. Additional covariates correspond to those of Tables 2 and 3. Standard errors that allow for serial correlation across observations of the same mother are reported in parentheses.

${ }^{a}$ Model (2) is based on a somewhat smaller sample of mothers. I exclude maternal observations from the year 2003, because information on alternative types of paid and unpaid care was not collected in 2003.

$* \mathrm{p}<0.1 * * \mathrm{p}<0.05 * * * \mathrm{p}<0.01$.

Sources: SOEPv30 (2003-2009) \& SPI NRW (2010), own estimates. 